\title{
Note
}

\section{An Idea Whose Time Has Come:}

\section{A Comparative Procedural History of the \\ Civil Rights Acts of 1960, 1964, and 1991}

\author{
Nicole L. Guéron
}

The congressional enactment of legislation involves many elements. Some are well known and well publicized: the clashes of personality, the cautious attention to public opinion and political ramifications, and the place of a bill within the larger political agenda of an administration or a legislature. Less visible, but no less influential, are the procedural mechanisms relied upon by members of Congress to transform a legislative aspiration into a binding law of the United States. A full analysis of the legislative process requires an understanding of the ways lawmakers use procedural tools to outmaneuver one another. Furthermore, procedure can be especially critical in the passage of legislation that addresses controversial issues such as race and civil rights, for legislators can escape public criticism or accountability by using procedural intricacies to mask the content of particular votes or committee recommendations. As Charles Tiefer, Deputy General Counsel to the Clerk of the House of Representatives, asserts, "Congressional procedure is the language of legislative action; its central aspects . . . have at least the meaningfulness and the importance-if not more-possessed by civil procedure as the language of the courts and international law as the language of diplomacy."

1. Charles tiefer, Congressional Practice and Procedure a Refikeicz, Restarch, isd

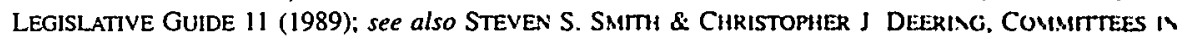


Despite congressional procedure's important effects on the passage of bills, laws are frequently analyzed without any discussion of their procedural histories. Almost every published study of the Civil Rights Act of $1991^{2}$ overlooks entirely the procedural events in the bill's evolution. Given the remarkable political events surrounding the Act's passage, perhaps it is not surprising that the few existing discussions of the bill's procedural history seem to begin and end with two names: Anita Hill and David Duke. ${ }^{3}$ Yet such a concentrated focus on the public political events of autumn 1991 ignores the vital procedural mechanisms that directed and shaped the 102d Congress and the 1991 Civil Rights Act. This Note uses the procedural history of the 1991 Act to demonstrate the power of congressional procedure in shaping legislation.

We cannot fully understand the passage of the 1991 Act without studying its procedural history; neither can we understand that procedural history without an examination of the origins of the procedural rules that shaped it. Many of the rules under which the $102 \mathrm{~d}$ Congress operated were the products of significant procedural reforms of the 1970's. As numerous studies of Congress and legislation in the 1960's and 1970's demonstrate, these reforms grew out of the dissatisfaction of liberal members of Congress with the disproportionate power of Congress' "conservative coalition," which had greatly obstructed the passage of measures such as the Civil Rights Acts of $1960^{5}$ and $1964 .^{6}$ The ensuing liberal procedural reforms diminished the

CONGRESS 1 (1984) ("Understanding how committees work is vital to understanding legislative decision making in Congress.").

2. Pub. L. No. 102-166, 105 Stat. 1071 (codified in scattered sections of 2 U.S.C., 16 U.S.C., \& 42 U.S.C. (Supp. V 1993)).

3. See, e.g., Compromise Civil Rights Bill Passed, 47 Cong. Q. AlmanaC 251, 251 (1992) (quoting Representative Washington suggesting that bill's passage was eased when "David Duke took the shect off that [quota] argument"); Jerome McCristal Culp, Jr., Neutrality. the Race Question, and the 199/ Civil Rights Act: The "Impossibility" of Permanent Reform, 45 RUTGERS L. REv. 965, 965 (1993) (arguing that desire to repay Senator Danforth for his help during Thomas hearings may have led President George Bush to sign Civil Rights Act); Neal Devins, Reagan Redux: Civil Rights Under Bush, 68 NoTre DAME L. REv. 955, 996 (1993) (reasoning that Hill-Thomas hearings and David Duke's political success in Louisiana may have changed popular perceptions of second Bush veto); Pamela Fessler et al., Rights Bill Rises from the Ashes of Senate's Thomas Fight, 49 CoNG. Q. WKLY. REP. 3124, 3124 (1991) (asserting that Bush Administration was feeling pressure on race and gender issues); Bob Cohn \& Clara Bingham, A Turnabout on Civil Rights, NEwSwEEK, Nov. 4, 1991, at 32 (stating that after Duke's success, "it suddenly became important for the White House to stop playing on racial fears and adopt a tone of moderation"); William Raspberty, Bush, Civil Rights and the Specter of David Duke, WASH. POST, Oct. 30, 1991, at A23 (op-cd claiming that Duke victory convinced Bush that "he'd rather have a civil rights bill he could sign than to hitch his political wagon to hard-core bigots").

4. The "conservative coalition" is composed of a block of conservative Southern Democrats and conservative Republicans. See, e.g., MACK C. SHelley II, THE PERMANENT Majority: THE CONSERVATIVE COALITION IN THE UNITED STATES CONGRESS (1983) (charting evolution, political patterns, and influence of conservative coalition); TIEFER, supra note 1, at 257-60 (describing interaction between conservative coalition and House Rules Committee).

5. Pub. L. No. 86-449, 74 Stat. 86 (codified as amended in scattered sections of 18 U.S.C., 20 U.S.C., \& 42 U.S.C. (1988 \& Supp. V 1993)).

6. Pub. L. No. 88-352, 78 Stat. 241 (codified as amended at 28 U.S.C. $\S 1447$ and in scattered sections of 5 U.S.C. \& 42 U.S.C. (1988 \& Supp. V 1993)). 
power of the conservative coalition by weakening the political power of its Southern Democratic members through changes in the seniority and committee leadership systems, cloture rules in the Senate, and the composition of the House Rules Committee.

This Note analyzes the procedural history of the Civil Rights Act of 1991 in comparison with the procedural histories of the 1960 and 1964 Civil Rights Acts in an effort to highlight the procedural reforms that took place within Congress in the intervening years and their impact on the passage of legislation. Because the 1991 Civil Rights Act had direct analogues in 1960 and 1964, it provides a useful test case for comparing two eras of legislative activity to see whether the procedural reforms of the 1970's made a difference in the passage of legislation. Part I of this Note recounts the procedural history of the Civil Rights Act of 1991. Part II describes, more briefly, the procedural histories of the Civil Rights Acts of 1960 and 1964. Part III focuses on specific procedural reforms of the 1970's and their impact on the 1991 civil rights legislation, through comparisons to the procedural maneuvers of 1960 and 1964. Part IV concludes that reforms concerning seniority, committec organization, and the House Rules Committee had a significant impact upon the passage of the 1991 Civil Rights Act, and increased the overall representativeness of Congress.

\section{A Procedural History of the Civil Rights ACT OF 1991}

On January 3, 1991, Representative Jack Brooks (D-Tex.) introduced House Bill 1 (H.R. 1), the Civil Rights and Women's Equity in Employment Act of 1991, on the floor of the House of Representatives. ${ }^{7}$ The bill was given the number H.R. 1 to symbolize its prominence on the legislative agenda and to underscore its need for immediate momentum, ${ }^{8}$ and was referred to both the Judiciary Committee and the Education and Labor Committee." H.R. I closely resembled Senate Bill 2104 (S. 2104), the Civil Rights Act of 1990, which had passed both chambers of Congress the year before only to be vetoed by President Bush and fail in an override attempt. ${ }^{10}$ The 1991 bill differed from the 1990 bill in a few of its specifics, including language defining the "business necessity" requirement of disparate impact suits" and the damages

7. 137 CONG. REC. H53, E14 (daily ed. Jan. 3. 1991)

8. Interview with Judith L. Lichtman, President, Women's Legal Defense Fund, in Neu Haven. Conn (Apr. 13, 1994).

9. 137 CONG. REC. H53 (daily ed. Jan. 3. 1991)

10. The Senate vote on October 24, 1990, fell one vote short of the tho-thurds required to overnde a veto. The final tally was 66 to 34, 136 CONG. REC. Si6.589 (dasly ed Oet 24. 1990,

11. The Supreme Court has interpreted Title VII of the Civil Rights Act of $196-1$ to prohibit not only intentional discrimination or "disparate treatment," but also unintentional discrimination that has a "disparate impact" on protected class members. See, e g. Gnggs s Duhe Pou er Co. 401 ('S $\$ 24$ (197)) Disparate impact exists if facially neutral selection or promotion cntena. for eximple, operale to exclude or reduce the opportunities of protected class members at a disproportionate rate $l d$ at $431-32$ Employers 
provision for intentional discrimination. ${ }^{12}$ The 1990 bill had created a punitive and compensatory damages remedy under Title VII of the 1964 Civil Rights Act for victims of intentional discrimination; ${ }^{13}$ a $\$ 150,000$ cap on these damages had been added to the 1990 bill as a compromise during the legislative battle. ${ }^{14}$ In 1991, however, the sponsors of H.R. 1 chose to introduce the civil rights bill without the damages cap. ${ }^{15}$ The Bush Administration followed a similar strategy in proposing its version of the 1991 Civil Rights Act, H.R. 1375, moving away from compromise positions it had accepted in $1990 .^{16}$ In the words of Representative Bill Goodling (R-Pa.), ranking Republican of the House Education and Labor Committee: "“[The Democrats] started more to the left. We started more to the right.",17

The 1991 Civil Rights Act moved rapidly through its first House committees under the guidance of their chairmen. ${ }^{18}$ On March 12, the House Education and Labor Committee, chaired by Representative William D. Ford (D-Mich.), approved H.R. 1 by a voice vote. ${ }^{19}$ The House Subcommittee on Civil and Constitutional Rights, chaired by Representative Don Edwards (DCal.), also approved the bill on the same date. ${ }^{20}$ The bill was then approved

may argue as an affirmative defense to a disparate impact charge that the challenged criteria are a "busincss necessity." Id. at 431 . In Wards Cove Packing Co. v. Atonio, 490 U.S. 642 (1989), the Court reinterpreted several aspects of disparate impact theory, thus raising numerous questions about the proper interpretation of business necessity doctrine. These issues included the extent to which business necessity would require that disputed hiring criteria be related to successful job performance, the location of the burden of proof of business necessity, and the specificity with which complaining employees or job applicants would have to pinpoint the employment practices that caused the disparate impact. President Bush's assertion that the 1990 bill would lead to hiring and promotional quotas was based on his interpretation of how the bill addressed these issues within the business necessity standard. See 136 CONG. REC. S16,418-19 (daily ed. Oct. 22, 1990) (President Bush's veto message).

12. Joan Biskupic, Backers Want Wavering Votes Lined Up for Antibias Bill, 49 CONG. Q. WKLY. REP. 745,745 (1991).

13. 136 CONG. REC. S9967 (daily ed. July 18, 1990).

14. Id. at H6810-13 (daily ed. Aug. 2, 1990) (debate on and passage of Brooks Amendment by vote of 289 to 134).

15. Adam Clymer, Battle over Rights Bills Emphasizes Sexıal Bias, N.Y. TıMES, Mar. 4, 1991, at Al4.

16. Devins, supra note 3, at 991.

17. Joan Biskupic, Bush Bill Moves to Right, 49 CoNG. Q. WKLY. REP. 684, 684 (1991) (quoting Rep. Goodling); see also Steven A. Holmes, Battle Lines Form on New Rights Bill, N.Y. TIMES, Feb. 8, 1991, at $A 16$ (" $[B]$ oth sides are much further apart than they were when negotiations to forge a compromise bill collapsed last fall.").

18. Most bills are examined and "marked up" by congressional subcommittees and committecs with jurisdiction over them. See CONGRESSIONAL QUARTERLY INC., HOW CONGRESS WORKS 41-42 (1983) [hereinafter HOW CONGRESS WORKS] (describing bill's progress through congressional committees). Committee jurisdiction can be ambiguous, and referrals may therefore reflect the political assessments of the majority leadership as to which committees will be friendlier to the legislation. See TIEFER, supra notc 1, at 110-33 (discussing committee jurisdiction, referrals, and multiple referrals). Bills may also be drafted using specific language in attempts to assure the jurisdiction of a particular committee. Id. at 114-18. Bills may be amended any number of times by committees and subcommittees. When a committee has finally decided on a version of the bill it supports, it sends the bill, accompanied by a committee report, to the floor of the congressional chamber. HOW CONGRESS WORKS, supra, at 41-42; see also discussion of Rules Committee infra note 24.

19. H.R. REP. No. 40, 102d Cong., 1st Sess., pt. 1, at 18 (1991).

20. 137 CONG. REC. D282 (daily ed. Mar. 12, 1991). 
by the full Judiciary Committee on March 19 by a vote of 24 to 10,21 with the support of all the Committee's Democrats and three Republicans, including the Committee's ranking minority member, Representative Hamilton Fish, Jr., of New York..$^{22}$ Both the Education and Labor Committee and the Judiciary Committee rejected the substitute versions of the bill proposed by committee Republicans for the Bush Administration. ${ }^{23}$ Remaining differences between the Education and Labor Committee and the Judiciary Committee versions of the bill were to be reconciled in the House Rules Committee. ${ }^{2 s}$

The Civil Rights Act's smooth progress through Congress was to end there. Since December of 1990 , civil rights activists had been negotiating over the bill's language with the Business Roundtable, a coalition representing about 200 large U.S. corporations, in the hope of crafting an acceptable compromise that the two-thirds of Congress needed to override a near-certain presidential veto could support. ${ }^{25}$ On April 9, White House Counsel C. Boyden Gray informed the negotiating business leaders of the Bush Administration's disapproval of the talks; ${ }^{26}$ the talks broke down several days later. Negotiators on both sides later charged that the talks had been scuttled by the White House, specifically by C. Boyden Gray and Chief of Staff John Sununu. ${ }^{27}$ Hopes for a bipartisan, White House-supported civil rights bill were shaken, and the bill's passage seemed in jeopardy.

In the next month, several compromise versions of the Civil Rights Act were developed, including a substitute proposed jointly by Representative Brooks, chairman of the House Judiciary Committee and lead sponsor of the

21. H.R. REP. No. 40, 102d Cong., Ist Sess., pt. 2. at 18 (1991)

22. Biskupic, supra note 12 , at 747 .

23. Compromise Civil Rights Bill Passed, supra note 3. at 253

24. Most bills that reach the floor of the House of Representatues must first travel through the House Rules Committee, where they are given a "spectal rule" that sets limis on the tume for debate and the number of amendments allowed. The Rules Commillee's powers include "sereening out some controversial bills, structuring floor consideration including deciding what amendments to allow, and settling jurisdictional disputes." TIEFER, supra note 1, at 252.

25. Negotiating for the Business Roundtable were business leaders from the Amencan Express Co . AT\&T, and the Business Roundtable itself. Negotatung for civil nghts groups were representatives from the Leadership Conference on Civil Rights, the Women's Legal Defense Fund, the NAACP. the NAACP Legal Defense and Educational Fund, the National Women's Law Center, and the Lawyers Commutte for Civil Rights. Sharon LaFraniere \& Gary Lee, White House Lobbres Businesses on Rights Bill. WASH POST. Apr. 13, 1991, at A7: Gary Lee. Behind Closed Doors. Cnil Rights Compromise. Wash POST. Apr 10. 1991, at A16.

26. LaFraniere \& Lee, supra note 25 , at A7 (noung "White House's growing concem that the Democrats and business groups will unite on an antidiscrimination bill and gain enough momentum in Congress to override a presidential veto"); see also Sharon LaFrantere. Bustnesses Reject Tulks on Rights Bill. Citing Bush Stance, WASH. POST. May 3.1991, at Al, All (“'IClorporate execuluves fecl White House opposition will doom any compromise they could come up with. according to business sources Roundtable representatives say they see no point in resuming talks unless Bush alters his stance.")

27. LaFraniere, supra note 26. at A11: LaFrantere \& Lee, supra note 25. at A7. Priseilla Painton. Quota Quagmure, TIME. May 27. 1991, at 21: William Raspberry. White House Compromise or Sabotage'. WASH. POST, Apr. 15, 1991, at A9. But see Gary Lee \& Sharon LaFraniere. Buseness Coaluton Pulls Out of Civil Rights Talks, WASH. POST, Apr. 20, 1991. at A1. A9 (quoung AT\&T Chamman Rober Allen's denial that he had been under "any pressure from the White House"). 
bill, and Representative Fish, ranking minority member of the House Judiciary Committee. The substitute, announced on May $21,{ }^{28}$ included three important provisions. First, it added a provision explicitly stating that the bill neither required nor permitted quotas. Second, it reinserted the cap on punitive damages available for intentional sex discrimination that had passed both chambers in 1990. Third, the Brooks-Fish substitute altered the language concerning the "business necessity" defense available to defendants in disparate impact lawsuits. ${ }^{29}$

The House Rules Committee convened on May 29 and 30 to write a Rule for H.R. $1 .^{30}$ Judiciary Committee Chairman Brooks and nine other Representatives testified before the committee at that time. ${ }^{31}$ The resulting Rule-House Resolution 162 (H.R. Res. 162)-provided for the House to resolve itself into the Committee of the Whole ${ }^{32}$ for three hours of general debate on the bill, to be equally divided between the minority and majority parties. ${ }^{33}$ The Rule then called for the amendment process to begin, with only three substitute amendments in order, and no amendments in order on those amendments. ${ }^{34}$ The amendments would be considered in a "King of the Hill" fashion, meaning that whichever of the proposed substitute amendments passed last would prevail. ${ }^{35}$ The three substitutes would be voted upon in specified order: first, the Towns-Schroeder substitute, which replaced H.R. 1 with the original, more liberal, version of the Civil Rights Act that had passed the House Education and Labor Committee in 1990; second, the Michel substitute, proposed by House Minority Leader Robert H. Michel (R-Ill.), which replaced H.R. 1 with H.R. 1375, the Administration's bill; and, last, the recently developed Brooks-Fish compromise substitute. ${ }^{36}$ After votes on all three

28. See Sharon LaFraniere \& Tom Kenworthy, Democrats Outline Revised Rights Bill, WASH. POST, May 22, 1991, at A5.

29. 137 CONG. REC. H3923-24, H3933-34 (daily ed. June 5, 1991) (amendment and summary of provisions); see also Joan Biskupic, Behind the Fight over Quotas Lie Divisive Racial Issues, 49 CoNo. Q. WKLY. REP. 1442, 1443-45 (1991).

30. See discussion of Rules Committee supra note 24.

31. 137 CONG. REC. D674 (daily ed. May 30, 1991).

32. The Committee of the Whole is a House parliamentary fiction-a temporary committee with a quorum of 100 members. How CONGRESS WORKS, supra note 18, at 51 . The House often transforms itself into the Committee of the Whole to debate and amend bills. Id. "The House uses the Committee of the Whole procedure because of the Committee's fast-paced and smooth amendment process that (1) basically allots only five minutes' debate on each side per amendment ... and (2) can end debate through the motion to close or to limit debate." TIEFER, supra note 1, at 35 n.47. The Committee of the Whole cannot pass a bill, How CONGRESS WORKS, supra note 18, at 51 , so it must "rise" when its debates are over and report back to the House of Representatives. Id. at 53.

33. 137 CONG. REC. H3809 (daily ed. June 4, 1991).

34. Id:; see also H.R. REP. No. 83, 102d Cong., Ist Sess. 1-33 (1991) (including text of threc amendments in order).

35. 137 CONG. REC. H3809 (daily ed. June 4, 1991).

36. H.R. REP. NO. 83, supra note 34 , at I-33 (including text of three amendments in order); 137 CONG. REC. H3824-25 (daily ed. June 4, 1991) (statement of Rep. Wheat, outlining Rule). This ordering of the amendments was perhaps an effort by the Rules Committee to assure the success of the Brooks-Fish compromise. With this ordering, both liberal and conservative members who supported the compromise as a second-best option could vote for their favored, more ideological proposals without jeopardizing the 
amendments, H.R. Res. 162 directed that "[t]he previous question shall be considered as ordered on the bill and amendment thereto to final passage without intervening motion except one motion to recommit." ${ }^{37}$

H.R. Res. 162 arrived on the House floor on June 4 and immediately came under heated minority criticism as an overly restrictive "gag rule." ${ }^{38}$ In addition, Representative Gerald B.H. Solomon (R-N.Y.) raised a complicated technical criticism of the Rule in a point of order. ${ }^{39}$ Representative Solomon asserted that the Rule oppressed the minority party by allowing only a straight motion to recommit, rather than a motion to recommit with amendatory instructions. Solomon argued that by excluding those words, the Rule denied the minority the right to use amendatory instructions to offer a final amendment and have a vote immediately recorded on that amendment. ${ }^{+0}$ Representative Alan Wheat (D-Mo.), majority floor manager of the Rule, responded that a recent parliamentary ruling had upheld a similar Rule calling for a motion to recommit without instructions." After listening to both arguments, the Speaker ruled in favor of the majority and allowed H.R. Res. 162 to stand as written. ${ }^{42}$

During general debate on the Rule, Representative Solomon returned to the topic of the motion to recommit, reading into the Congressional Record data on the Rules written for fifteen previous major civil rights bills. ${ }^{3} \mathrm{He}$ reminded members that the Rules for nine of these fifteen recent bills had been completely open and noted that, on three other occasions, civil rights bills had proceeded under a suspension of the rules. ${ }^{\text {th }}$ Representative Solomon again urged the House to adopt an open Rule, arguing to the Democrats that "[y]ou have a 2 to 1 -plus majority. What are you afraid of ? ? $]^{\text {'ss }}$

The House Democrats remained unmoved. After one hour of debate on H.R. Res. 162, Representative Wheat moved the previous question on the

success of the compromise. Because members would vote on the Brooks-Fish compromise last, if they voted first for the liberal or conservative proposal, but then supported the compromise, the compromise would pass.

37. 137 CONG. REC. H3809 (daily ed. June 4, 1991). A motuon for the previous questuon culs off further debate on the underlying matter and brings it to a direct vote. TiEFer, supra note 1, at 369-70.

38. 137 CONG. REC. H3812 (daily ed. June 4. 1991) (statement of Rep. Solomon)

39. Id. at H3810. Representative Solomon relied on House Rule XI. clause 4 (b). which stales that "[t]he Committee on Rules shall not repon any rule or order. . Which would present the motion to recommit from being made as provided in clause $\$$ of Rule XVI." CLERX OF TIE HOLSE OF REPRESENTATIVES, 1015T CONG., 2D SESS., RULES OF THE House of RePresentatives 15 (1990) (Donnald K. Anderson). House Rule XVI, clause 4. states that "lalficr the previous question sthall have been ordered on the passage of a bill or joint resolution one motion to recommil shall be in order, and the Speaker shall give preference in recognition for such purpose to a Member who is opposed to the bill or joint resolution." Id. at 19.

40. 137 CONG. REC. H3811 (daily ed. June 4. 1991) (statement of Rep. Solomon)

41. Id. at $\mathrm{H} 3810$.

42. Id. at $\mathrm{H} 3811$.

43. Id. at $\mathrm{H} 3813$.

44. Id. at $\mathrm{H} 3812$.

45. Id. 
Rule. ${ }^{46}$ The motion passed 259 to 165 in a party-line vote, with no Republicans voting in favor of the motion and only one Democrat voting against it. ${ }^{47}$ The House then voted on the Rule itself. H.R. Res. 162 passed by a vote of 247 to 175 with similar partisan support: 6 Republicans in favor and 159 opposed, 240 Democrats in favor and 16 opposed. $^{48}$

Once the House had agreed to the Rule for H.R. 1, the bill itself advanced without procedural complications. Pursuant to H.R. Res. 162, the House rose and resolved itself into the Committee of the Whole ${ }^{49}$ for consideration of H.R. 1, with Representative Kwesi Mfume (D-Md.) as its chair. ${ }^{50}$ Representative Mfume recognized the bill's lead sponsor, Representative Brooks, as majority floor manager and Representative Henry Hyde (R-Ill.) as minority floor manager for three hours of general debate, equally divided. ${ }^{51}$ After the debate, the Committee of the Whole turned to the Towns-Schroeder amendment, which it debated for one hour and rejected by a vote of 152 to 277. ${ }^{52}$ The Committee next debated the Michel substitute for one hour, and voted to reject it, 162 to $266 .{ }^{53}$ Representative Brooks then successfully moved that the Committee rise for that evening. ${ }^{54}$

The next day, June 5, 1991, the House again resolved itself into the Committee of the Whole to consider the Brooks-Fish substitute amendment. After one hour of debate, the amendment passed by a vote of 264 to $166 .{ }^{55}$ The amended version of the bill then passed by voice vote, and the Committee of the Whole rose and reported H.R. 1 back to the House. ${ }^{56}$ The House then voted on the passage of H.R. 1; the bill passed by a vote of 273 to $158 .^{57}$ Despite the efforts of the bill's supporters, the count was fifteen votes short of the two-thirds majority needed for an override vote. ${ }^{58}$

H.R. 1 was read for the first time on the Senate floor on June 11, 1991..$^{59}$ The Senate did not attach much importance to the bill, however, because of

46. Id. at $\mathrm{H} 3832 ;$ see also supra note 37.

47. 137 CONG. REC. H3832-33 (daily ed. June 4, 1991).

48. Id. at H3833. The remaining vote in favor of the Rule was cast by Representative Bernic Sanders of Vermont, who was registered as an Independent and consistently voted with the Democrats throughout the debates on and passage of the Civil Rights Act of 1991.

49. See supra note 32.

50. 137 CONG. REC. H3834 (daily ed. June 4, 1991). When the House is in the Committee of the Whole, the Speaker appoints a member of his or her party to preside as Chair. How CONGRESS WORKS, supra note 18 , at 51 .

51. 137 CONG. REC. H3834 (daily ed. June 4, 1991) (statement of Rep. Mfume).

52. Id. at H3896 (daily ed. June 5, 1991).

53. Id. at $\mathrm{H} 3908-09$.

54. Id. at $\mathrm{H} 3909$.

55. Id. at $\mathrm{H} 3958$.

56. Id.

57. Id. at $\mathrm{H} 3958-59$.

58. Reports vary as to the exact numbers required for a veto override; the numbers used in the text were reported in the Congressional Quarterly Weekly Report. See Joan Biskupic, Bill Passes House, Not Muster; Next Chance Is in Senate, 49 CONG. Q. WKLY. REP. 1498, 1498 (1991).

59. 137 CONG. REC. S7462 (daily ed. June 11, 1991). 
allegations that it was a "quota bill." House to obtain a veto-proof majority. At least two other civil rights proposals had already been introduced in the Senate by that time. The Bush Administration's bill, S. 611, had been introduced on March 12, 1991. ${ }^{\text {b1 }}$ Three other bills. S. 1207, S. 1208, and S. 1209, formed a three-part proposal introduced on June 4 by Senator John C. Danforth (R-Mo.). ${ }^{62}$ Danforth's proposal differed from the Administration's bill primarily in its treatment of the Martin v. Wilks ${ }^{63}$ case and in its "business necessity" language. Senator Danforth sought the Bush Administration's support for his bills throughout the month of June, finally asserting in frustration that the White House was stalling on the issue. ${ }^{65}$ Furthermore, as reported in The New York Times, "[ $\mathrm{t}$ ]he suspicion that $\mathrm{Mr}$. Bush is more interested in having an issue-the idea that the Democrats support quota hiring to benefit blacks and women-than a bill is widely held in this city, and not just by partisan Democrats.

Meanwhile, in the middle of Senate consideration of a crime bill on June 25, Senator Jesse Helms (R-N.C.) rose to place a second-order amendment on an amendment concerning handguns. ${ }^{67}$ Senator Helms' amendment, No. 378. proposed to alter Title VII of the 1964 Civil Rights Act to prohibit "preferential treatment" (which was not defined) in employment based on race, sex, color, national origin, or religion. ${ }^{68}$ Apparently, Senator Helms was attempting to preempt the civil rights bill. Many Senators, however, including Minority Leader Bob Dole (R-Kan.), argued against the amendment; they pointed to negotiations surrounding the civil rights bill and asserted that a crime bill was the wrong place to consider the inflammatory issues of quotas and affirmative action. ${ }^{69}$ After several hours of debate, Majority Leader George J. Mitchell (D-Me.) moved to table the Helms amendment, and the motion passed, 71 to $28 .^{70}$

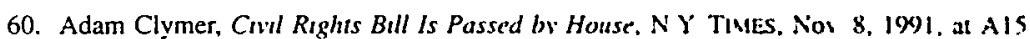

61. 137 CONG. REC. $\$ 3020$ (daily ed. Mar. 12, 1991).

62. Id. at S7020-26 (daily ed. June 4. 1991).

63. 490 U.S. 755 (1989) (refusing to preclude white firefighters in Birmungham. Alabama. from making collateral attack on consent decree between black firefighters and City of Birmungham that included numerical goals for hiring and promotions. reasoning black firefighters should hase jouned white tiretighters as necessary parties in suit).

64. See Biskupic, supra note 58. at 1498-99. 1502. Adam Clymer. Rights Spothght on G O P. XY TIMES, June 7, 1991, at A1, A24: see also supra note 11

65. Helen Dewar \& Sharon LaFraniere. GOP Senators Abandon Efforts on Compromuse Cud Rughts Bill, WASH. POST, June 28. 1991, at A7.

66. Clymer, supra note 64. at Al.

67. 137 CONG. REC. S8560 (daily ed. June 25. 1991). Senator Helms' procedural move is somewhal ironic because it mirrors the steps taken by Senator Lyndon B. Johnson in 1960 Johnson explotted the Senate's lack of germaneness requirements for amendments to get esvl rights legislation onto the Senate floor. See infra text accompanying note 109. Of course. the two Senators used the same procedural maneuvers to achieve different substantive goals

68. 137 CONG. REC. S8560 (daily ed. June 25, 1991)

69. See, e.g.. Id. at S8684, S8677, S8680 (daily ed. June 26. 1991) (statements of Sens Breaux. Dole. and Kennedy).

70. Id. at S8731-32 (daily ed. June 27. 1991). 
Senate efforts to compromise on a civil rights bill continued throughout the summer of 1991. On June 27, Senator Danforth revised his proposed bills after negotiations with the White House and reintroduced them as S. 1407, S. 1408, and S. 1409. ${ }^{71}$ Nevertheless, on August 1, Danforth reported that President Bush had rebuffed his most recent attempt at compromise. ${ }^{72}$ The Senator tried again in September ${ }^{73}$ incorporating language from the White House-approved Americans with Disabilities Act of $1990^{74}$ into the newest version of the bill. This version, S. 1745, was introduced on the Senate floor on September 24, $1991 .^{75}$ This Danforth effort also appeared destined for White House disapproval, however, ${ }^{76}$ and the bill seemed to tread water in the Senate until October.

On October 7, Senator Mitchell moved to proceed to S. 1745 and sent a cloture motion signed by sixteen Senators to the Senate President's desk. ${ }^{77}$ The cloture motion was delayed, however, because of the rapidly unfolding events surrounding the confirmation of Clarence Thomas to the U.S. Supreme Court, ${ }^{78}$ Mitchell reintroduced the motion on October $17 .{ }^{79}$ On October 22, one week after the Senate voted to confirm Thomas, ${ }^{80}$ and four days after former Ku Klux Klan Grand Wizard David Duke was named the Republican candidate in the Louisiana gubernatorial runoff election, ${ }^{81}$ the Senate voted 93 to 4 in favor of cloture on S. $1745{ }^{82}$

From there, action was rapid. On October 25, President Bush held a press conference to announce his support for the latest compromise on the Civil Rights Act, stating that " " $[t]$ his agreement was reached last night in marathon negotiations, shepherded by Senator John [C.] Danforth of Missouri, nurtured

71. Id. at $\$ 8983$ (daily ed. June 28, 1991); Leslie Rigby, Benchmarks, 49 CONG. Q. WKLY. REP. 3126 (1991).

72. Joan Biskupic, Civil Rights: No Deal, 49 CONG. Q. WKLY. REP. 2170, 2170 (1991).

73. Helen Dewar, Danforth Alters Wording in Rights Compromise, WaSH. POST, Sept. 21, 1991, at A6 ("We have incessantly tinkered with this [civil rights] bill in order to attempt to please the administration .... I don't see how anyone could say no to it' ...." (quoting Sen. Danforth)).

74. Pub. L. No. 101-336, 104 Stat. 327 (1990) (codified in scattered sections of 29 U.S.C., 42 U.S.C., \& 47 U.S.C. (Supp. V 1993)).

75. 137 CONG. REC. S13,581 (daily ed. Sept. 24, 1991).

76. Helen Dewar, Administration Rejects Danforth's Rights Plan, WASH. POST, Sept. 25, 1991, at A4 ("Asked if [the Administration's opponents of civil rights legislation] might include White House Chicf of Staff John H. Sununu, Danforth said, 'That's possible.'").

77. 137 CONG. REC. S14,493 (daily ed. Oct. 7, 1991). The Senate allows for virtually unlimited debate on bills; the only ways to end debate are by unanimous consent agreement or by voting "cloture" on the bill. HOW CONGRESS WORKS, supra note 18, at 58. Under Senate Rule XXII, a cloture petition, if signed by 16 members, constitutes a formal motion to end debate. S. Doc. No. 1, 102d Cong., 1st Sess. 21-23 (1992) (Senate Manual). If three-fifths of the Senate approves cloture, debate is then brought to a close. $I d$; see discussion of cloture rule changes infra note 112 .

78. See Phil Kuntz, Mired in Procedural, Political Mess . . Senate Scrambled To Delay Vote, 49 CONG. Q. WKLY. REP. 2954, 2954-55 (1991).

79. 137 CONG. REC. S14,931-32 (daily ed. Oct. 17, 1991).

80. Id. at $\$ 14,704-05$ (daily ed. Oct. 15, 1991) (confirming Thomas by vote of 52 to 48).

81. Roberto Suro, Louisiana Puts Ex-Klan Leader in Runoff Race, N.Y. TIMES, Oct. 21, 1991, at A1.

82. 137 CONG. REC. S14,963 (daily ed. Oct. 22,1991 ). 
by Senator [Bob] Dole and other leaders of both parties." ${ }^{183}$ On October 28 , the Senate passed, by a vote of 92 to 0 , a nonbinding sense-of-the-Senate resolution, ${ }^{84}$ S. Res. 209, which suggested that the Senate consider changing the federal laws and Senate rules to prevent sexual harassment. ${ }^{85}$ On October 29 , the Senate disposed of numerous amendments and a constitutional point of order on S. $1745 .{ }^{86}$ Finally, on October 30 , several more amendments were considered, and the Senate voted on the bill's passage. ${ }^{87}$ The Civil Rights Act of 1991 passed the Senate by a vote of 93 to $5 .{ }^{88}$

Because of the highly contested language alterations that had occurred during the bill's passage, the Senate approved a three-paragraph "interpretive memorandum" that explained the Act's use of the term "business necessity." 89 On October 29 , the Senate agreed by voice vote to direct all courts to the three paragraphs for resolution of any interpretive questions. ${ }^{90}$ At least one scholar has pointed to this congressional failure (or refusal) to resolve statutorily one of the difficult definitional problems of the Act as an explanation for its passage:

The key to the compromise was the bill's failure to conclusively define business necessity. Instead, by reference to an interpretive memo, the 1991 Act said that judicial interpretation of "business necessity" should be governed by the "concepts enunciated by ... Supreme Court ... decisions prior to Wards Cove Packing Co. v. Atonio." 91

Finally, S. 1745 was presented to the House of Representatives for approval: The Rules Committee reported it to the floor on November 7, 1991, with H.R. Res. 270, an entirely closed Rule allowing only one hour of general debate and no amendments. ${ }^{92}$ Liberal Democrats opposed the Rule, arguing that the House should have the opportunity to remove from the Senate bill a provision exempting from the bill's coverage the ongoing lawsuit against the

83. Bush News Conference on Civil Rights Accord, N.Y. TIMES, Oct 26. 1991, at A7 (aiteralions in original) (quoting President Bush).

84. See generally HOW CONGRESS WORKS. supra note 18. at 41 (descnbing resolutions expressing "sense" or opinion of chambers). The fact that "sense-of-the-Senate" resolutions do not have the force of law suggests that S. Res. 209 was passed to respond quickly and casily to the political pressure generaled by Anita Hill's allegations of sexual harassment.

85. 137 CONG. REC. S15,290-91 (daily ed. Oct. 28. 1991)

86. Id. at D1325-26 (daily ed. Oct. 29. 1991).

87. Id. at D1336-37 (daily ed. Oct. 30, 1991).

88. Id. at $\$ 15,503$.

89. Id. at $\$ 15,276$ (daily ed. Oct. 25, 1991) (declanng these paragraphs "exclusive legislatue hustory" of Act) (codified at 42 U.S.C. \$ 1981 note (Supp. V 1993)); see also supra note 11

90. Id. at S15,362 (daily ed. Oct. 29. 1991).

91. Devins, supra note 3, at 995 (quoting "exclusive legislatuve huston" at 137 CONG REC S15,276 (daily ed. Oct. 25, 1991)).

92. 137 CONG. REC. H9505 (daily ed. Nor. 7. 1991) 
Wards Cove Packing Company. ${ }^{93}$ Representative Wheat, floor manager of H.R. Res. 270, justified the Rule by referring to the two years of bitter struggle underlying the Civil Rights Act, claiming that "this is an extraordinary situation and thus we have an extraordinary Rule." "94 Even opponents of the Rule acknowledged this political backdrop: "[T]he Rules Committee was forced to adopt a closed rule, because the White House said the bill [would] be vetoed if [the] Wards Cove exemption [were] removed."95 On November 7, H.R. Res. 270 was adopted by a vote of 327 to $93 .{ }^{96}$ After brief debate, the House then voted in favor of final passage of S. 1745 by a vote of 381 to $38 .{ }^{97}$ President Bush signed the bill into law on November 21, $1991 .^{98}$

\section{Procedural Histories of THE Civil Rights ACTS OF 1960 AND 1964}

Full procedural histories of the passages of the 1960 and 1964 Civil Rights Acts appear in numerous books and articles on the subject. ${ }^{99}$ This summary therefore does not discuss extensively the events and politics shaping the bills. Instead, this Part focuses on specific procedural issues that arose during the passages of the Acts for purposes of comparison with procedural events that marked the passage of the 1991 Civil Rights Act.

\section{A. The Civil Rights Act of 1960}

During the 1959 session of the Eighty-Sixth Congress, attempts at passing a civil rights act came up short. Recalcitrant committee chairs in both the

93. See, e.g., id. at H9506 (statement of Rep. McDermott) (stating that Wards Cove workers' "quest for justice will be sacrificed on George Bush's altar of racial politics"); id. at H9509 (statement of Rep. Mink) (stating that Wards Cove exemption "debases the very title of this bill"); id. at H9511 (statement of Rep. Schroeder) (insisting that "special interest legislation in a civil rights bill is absolutely intolerable"); id. (statement of Rep. Mineta) (calling Wards Cove exemption "one of the most outrageous pieces of special interest legislation I have ever seen"). The Wards Cove exemption was inserted into the Senate bill on November 5 by a special corrective resolution, S. Res. 214. Id. at S15,950-68 (daily ed. Nov. 5, 1991). The exemption reads: "[N]othing in this Act shall apply to any disparate impact case for which a complaint was filed before March 1, 1975, and for which an initial decision was rendered after October 30, 1983." Pub. L. No. 102-I66, § 402, 105 Stat. 1071,1099 (codified at 42 U.S.C. $\$ 1981$ note (Supp. V 1993)). This exemption is extraordinary because it precludes relief for a group of plaintiffs whose efforts were a crucial causal factor in creating the need for the legislation.

94. 137 CONG. REC. H9505 (daily ed. Nov. 7, 1991).

95. Id. at $\mathrm{H} 9506$ (statement of Rep. McDermott).

96. Id. at $\mathrm{H} 9516$.

97. Id. at H9557-58.

98. Statement on Signing the Civil Rights Act of 1991, 1991 PUB. PAPERS 1504 (Nov. 21, 1991); 137 CONG. REC. D1490 (daily ed. Nov. 21, 1991).

99. See, e.g., DANiel M. Berman, A Bill Becomes a law: The Civil Rights ACT of 1960 (1962) [hereinafter BERMAN, A BILl BECOMES A LAW]; DANIEL M. BERMAN, A BILl BeCOMES A LAW: CONGRESS ENACTS CIVIL RIGHTS LEGISLATION (2d ed. 1966) [hereinafter BERMAN, A BILL BECOMES A

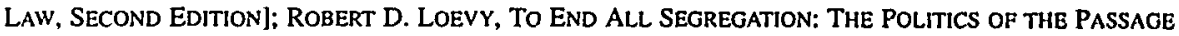
OF THE Civil Rights ACT OF 1964 (1990); Charles Whalen \& Barbara Whalen, The longest Debate: A Legislative History OF THE 1964 Civil Rights ACT (1985). 
House and Senate buried proposed civil rights bills and prevented them from ever reaching the chamber floors. ${ }^{100}$ For example, under the leadership of liberal Chairman Emanuel Celler (D-N.Y.), the House Judiciary Committee did receive $^{101}$ and report out ${ }^{102}$ a bill, H.R. 8601 , but it promptly stalled in the House Rules Committee, which was chaired by civil rights foe Howard W. Smith (D-Va.). ${ }^{103}$ The Senate version of that bill, S. 2721, was channeled to the Senate Judiciary Committee, ${ }^{104}$ chaired by Senator James O. Eastland (DMiss.), who had turned the committee into a "graveyard of civil rights legislation." 105 Attempts in both chambers to escape the obstructionist committees, including a House discharge petition filed by Representative Celler, ${ }^{106}$ were fruitless, and 1959 ended without the passage of civil rights legislation. ${ }^{107}$

In 1960, Senator Lyndon B. Johnson (D-Tex.) took a more aggressive approach by bypassing the Senate Judiciary Committee altogether. On the morning of February 15, 1960, he introduced H.R. 8315, which authorized the Secretary of the Army to lease land to certain Missouri schools. ${ }^{\text {tos }}$ Johnson then took advantage of the Senate's lack of germaneness rules and added to the bill an amendment encompassing the failed civil rights legislation of 1959. ${ }^{10 \%}$ Senator Johnson had chosen carefully: The bill was a useful vehicle not only to avoid Senator Eastland's Judiciary Committee and get a civil rights bill onto the Senate floor, but also to minimize later stonewalling in the House of Representatives because the House had already passed it." Senators were outraged by Senator Johnson's move; Senator Richard B. Russell (D-Ga.), for instance, declared that "that is not the way the Senate operates. That is a political carnival."1" Nevertheless, a civil rights bill had reached the Senate floor.

Of course, passage of the bill would not be so simple. The Senate's absence of rules that limit debate permits endless filibustering of controversial issues like the civil rights legislation. In 1960, Senate Rule XXII allowed a cloture petition to end debate only if two-thirds of those Senators present and voting agreed that debate should end. ${ }^{112}$ On March 8, thirty-one

100. See BERMAN, A BILL, BECOMES A LAw, supra nole 99, at 7-37

101. 10S CONG. REC. 15,398 (1959).

102. Id. at 16,621 .

103. See BERMAN, A Bill BeCOMEs a LAw, supra note 99 . at 22

104. 105 CONG. REC. 19,682 (1959).

105. WHALEN \& WHALEN, supra note 99 , at 4.

106. See BERMAN, A Bill BeCOMES A LAw, supra nole 99. at 23-25

107. See id. at 36-37.

108. 106 CONG. REC. 2444 (1960).

109. Id. at 2470. Senator Johnson did not place the text of the amendment on the excord id

110. BERMAN, A BILL BECOMES A LAW, supra note 99 , at 53, 55

111. 106 CONG. REC. 2474 (1960).

112. S. Doc. No. 2, 87th Cong.. Ist Sess. 23 (1961) (Senate Manual). From 1917 to 1949, Senate Rule XXII provided for cloture only with the suppon of two-thirds of those Senators present and voting From 1949 to 1959, that rule was tightened, requiring the approval of two-thurds of the enture Senate membership 
Senators-fifteen more than were necessary to bring a vote on cloture to the Senate floor ${ }^{113}$-filed a cloture petition. ${ }^{114}$ The vote two days later fell far short of two-thirds: Only forty-two Senators supported cloture while fifty-three opposed it. ${ }^{115}$ The filibuster continued, and as pressure for a more moderate civil rights bill mounted, eyes turned toward the House to see what sort of bill the Representatives could pass. ${ }^{116}$

The House of Representatives was still facing the same obstacle as in 1959-Rules Committee Chairman Howard Smith-and was still attempting to use the same weapon to wrest civil rights legislation from his control: the discharge petition. Under House Rule XXVI(4), discharge petitions could be filed by any House member once a bill had stood before any committee for more than thirty days or before the Rules Committee for seven days. ${ }^{17}$ Such petitions required the signatures of a majority of House members (218) to succeed. ${ }^{118}$ Liberal Democrats had acquired only 175 signatures on their discharge petition for H.R. 8601 when the names were leaked to The New York Times and promptly printed on January $22,1960 .{ }^{119}$ Because the petition was signed by 145 Democrats but only 30 Republicans, House Republicans suddenly came under great pressure to add their signatures to the petition to avoid appearing as though they were stalling the civil rights bill. ${ }^{120}$ When the number of signatures on the petition grew so that it seemed he might actually lose control of the bill, Chairman Smith finally gave in and announced hearings on H.R. 8601, ${ }^{121}$ which began on February 4, 1960. ${ }^{122}$ When the Committee finally wrote a Rule (H.R. Res. 359), Minority Leader Charlie Halleck (R-Ind.) encouraged Republicans to support it in order to share political credit for advancement of the bill. ${ }^{123}$ H.R. Res. 359 was therefore successfully reported out of the Rules Committee on February 23, 1960.124 The Rule allowed for fifteen hours of general debate on H.R. 8601, followed

for cloture to pass. How CONGRESS WORKS, supra note 18, at 60-63 (describing evolution of cloture rule). In 1959, Senate Majority Leader Johnson pushed for and won a return to the pre-1949 formula. S. Doc. No. 2, supra, at 23 . The rule stayed that way until the 1975 revisions, which required only a threc-fifths vote of the entire Senate membership for cloture. S. Doc. No. 1, 95th Cong., 1st Sess. 23-25 (1977) (Senate Manual). The three-fifths rule remained in effect in 1991. S. Doc. No. I, supra note 77, at 21-23.

113. The signatures of 16 Senators were needed to initiate a cloture petition under Senate Rule XXII.

S. DoC. No. 2, supra note 112 , at 23 .

114. 106 CONG. REC. 4933 (1960).

115. Id. at 5118 .

116. BERMAN, A BILL BECOMES A LAW, supra note 99 , at 72 .

117. H.R. DoC. No. 458, 86th Cong., 2d Sess. 478-79 (1959) (House Manual); see also How CONGRESS WORKS, supra note 18 , at 55.

118. H.R. DOC. No. 458, supra note 117 , at 479 ; see also How CONGRESS WORKS, supra note 18 , at 55 .

119. 175 in House Sign Civil Rights Plea, N.Y. TIMES, Jan. 22, 1960, at A11; List of 175 Supporters of Civil Rights, N.Y. TIMES, Jan. 22, 1960, at A11.

120. BERMAN, A BILL BECOMES A LAW, supra note 99, at 75.

121. Id.

122. 106 CONG. REC. D52 (1960).

123. BERMAN, A BILL BECOMES A LAW, supra note 99 , at 78-79.

124. 106 CONG. REC. 3259 (1960). 
by amendments; ${ }^{125}$ it passed on March 10, 1960, by a vote of 312 to $93 .^{136}$ The bill itself passed the House on March 24. by a vote of 311 to 109."

On March 24, Senator Johnson asked the Senate Clerk to read H.R. 8601 on the Senate floor for the first time. ${ }^{128}$ Senator Eastland then requested that the bill be referred to the Judiciary Committee without instruction, thus without any time limit for reporting the bill back to the full Senate. ${ }^{129}$ The Senate rejected Eastland's proposal 19 to $72,{ }^{130}$ and approved instead, 86 to 5, a referral to the Committee with a five-day time limit for its examination of the bill. ${ }^{131}$ Thus, on March 30, 1960, the Senate addressed H.R. 8601. "'2 After several days of debate on the bill, the Civil Rights Act came before the full Senate for a vote on April 8, 1960, and passed by a vote of 71 to $18 .^{13} \mathrm{~A}$ common final step in a bill's passage, reconciliation in a conference committec of the bills passed by the two chambers, ${ }^{1 / 4}$ was unnecessary in this case because on April 21, the House voted 288 to 95 to accept the Senate amendments to the bill. ${ }^{135}$ The Civil Rights Act of 1960 was signed into law by President Eisenhower on May 6, 1960. ${ }^{136}$ The Senate filibuster had taken its toll, however: ${ }^{137}$ Thurgood Marshall pronounced the bill not "'worth the paper it's written on.",138

\section{B. The Civil Rights Act of 1964}

The passage of the Civil Rights Act of 1964 featured many of the same procedural dramas as the 1960 passage, with a background of even greater national awareness, anxiety, and pressure.

On June 20, 1963, Judiciary Committee Chairman Emanuel Celler introduced a civil rights bill, H.R. 7152, which was promptly referred to the Judiciary Committee. ${ }^{139}$ As he had in 1960. Celler used his liberal Subcommittee No. 5 to hold hearings and mark-up on the bill, ${ }^{1+0}$ until, on October 8 , the full Judiciary Committee began consideration of H.R. $7152 .^{141}$

125. Id. at 5192-93.

126. Id. at 5198-99.

127. Id. at 6512 .

128. Id. at 6451 .

129. Id. at 6452 .

130. Id. at 6454-55.

131. Id. at 6455; see also BERMAN. A BILL BECOMES A LAW. supra note 99. at 97

132. 106 CONG. REC. 6931 (1960).

133. Id. at 7810-11.

134. For a discussion of conference committees. see generally TIEFER, supra note 1. at 767-71

135. 106 CONG. REC. 8507-08 (1960).

136. Statement by the President upon Signing the Civil Rights Act of 1960. 1960-61 Pt 8 P P PERS 398 (May 6, 1960): 106 CONG. REC. D497 (1960).

137. Gary Orfield, Congressional Power: Congress and Soclal Chayge 43 (1975)

138. BERMAN, A BILL BECOMES A LAW, SECOND EDITION, supra note 99. al 135 (quoung Marshall)

139. 109 CONG. REC. 11,252 (1963).

140. WHALEN \& WHALEN, supra note 99, at 40-41.

141. 109 CONG. REC. D485 (1963). 
Celler's bill, however, faced difficulties in the full committee. Although his subcommittee had reported out a strong bill, Celler knew that such a bill would not survive in the Rules Committee or on the House floor, and that compromises were necessary for passage. ${ }^{142}$ On October 22 , however, Representative Arch Moore (R-W. Va.) moved to report H.R. 7152 to the full House without modification. ${ }^{143}$ Representative Celler immediately adjourned the committee meeting ${ }^{144}$ and turned to President Kennedy for assistance. ${ }^{145}$ The next evening, the President met with House majority and minority leaders to try to persuade them to vote against the Moore motion and to craft a compromise that could survive a full House vote. ${ }^{146}$ President Kennedy was successful: Representative William McCulloch (R-Ohio), the ranking minority member of the Judiciary Committee, worked with House Democrats and Justice Department officials to craft a compromise bill that the Committee accepted by a vote of 20 to 14 on October $29,1963 .{ }^{147}$

The newly amended H.R. 7152 next had to face Representative Smith, still Chairman of the House Rules Committee. Although the House had enlarged the Rules Committee in 1961, raising the number of Democrats to ten from the previous eight, ${ }^{148}$ the Committee was still a significant roadblock for civil rights legislation. Confrontation with the Rules Committee and attempts to escape it thus led to extensive procedural manipulations of the House rules in 1963. Supporters of H.R. 7152 had three possible options for wresting the bill

142. WHALEN \& WHALEN, supra note 99 , at 49.

143. H.R. REP. No. 914, 88th Cong., Ist Sess. 63 (1963) (minority report).

144. Id.

145. LOEVY, supra note 99 , at 70 .

146. WHALEN \& WHALEN, supra note 99 , at 50 . It is understandable that conservatives opposed to civil rights legislation would have been happy to support the Moore motion-an unrealistically strong bill would have certainly died on the House foor. More interesting is Attorney General Robert F. Kennedy's assessment of the motives of liberal civil rights supporters for reporting such a bill out of committec: "[Liberals] would rather lose the whole bill and lose the legislation than make the kind of effort we wished. An awful lot of them ... were in love with death." Id. at 53.

147. 109 CONG. REC. D522 (1963); see also LOEVY, supra note 99, at 71.

148. 107 CONG. REC. 1589-90 (1961) (passage of amendment to enlarge committee); see also H.R. Doc. No. 619, 87th Cong., 2d Sess. 352 (1963) (House Manual) (reporting committee size change); How CONGRESS WORKS, supra note 18, at 96 (calling enlargement "House revolt" against conservative grip on power). The 1961 expansion was perceived by some Representatives as a political attempt to "pack" or "purge" the Rules Committee in order to advance a liberal agenda. See, e.g., 107 CoNG. REC. 1575 (1961) (statement of Rep. Brown) (asserting resolution was designed for single purpose of packing Rules Committee); id. at 1577 (statement of Rep. Arends) (claiming proposal would turn Rules Committce into "rubberstamp" of leadership); id. at 1578 (statement of Rep. Judd) (same); id. at 1583 (statement of Rep. Weaver) (implying committee-packing plan was political maneuver); id. at 1585 (statement of Rep. Poff) (arguing that "purging" Rules Committee would usurp its independent power). Other Representatives argued that the proposal would democratize the Rules Committee by decreasing the disproportionate, obstructionist power of its conservative coalition, thereby allowing the House to vote on important issues of the day. See, e.g., id. at 1581-82 (statement of Rep. Yates) (including in House record newspaper article calling for Rules Committee to "let the House vote"); id. at 1582 (statement of Rep. Blatnik) (arguing that conservative coalition had "stranglehold" on Rules Committee); id. at 1586 (statement of Rep. Moorhead) (stating that vote would test members' belief in process of representative democracy). This debate reveals that expansion of the committee was proposed and passed in order to decrease the ability of the Rules Committee to block legislation. Cf. infra text accompanying notes 270-74. 
from the grasp of the Rules Committee: the discharge petition (House Rule XXVII), Calendar Wednesday (House Rule XXIV), and House Rule XI.

Liberal Democrats began with the first method. Replicating his 1960 strategy, on December 9, 1963, ${ }^{149}$ Representative Celler filed a discharge petition, which was promptly signed by one hundred other members of the House. ${ }^{150}$ Republican Representatives alleged that the petition was merely an attempt to embarrass Republicans who had not signed it, and responded to the effort by arguing for bringing H.R. 7152 to the House floor as soon as possible under Calendar Wednesday. ${ }^{151}$ Under Calendar Wednesday rules, a committee member could call up to the floor and members could vote on any unprivileged bill, thus avoiding roadblocks set up within a committec." Striking back politically, Republicans publicly urged those Democrats who truly wanted to pass civil rights legislation to use Calendar Wednesday to call up H.R. 7152 on December 11, 1963, the soonest available date. "' As both the Republicans and the bill's supporters well knew, however. Calendar Wednesday procedure contained provisions that would have sunk H.R. 7152 . Because House Rule XXIV(7) required that a bill be disposed of by the end of the legislative day. ${ }^{154}$ any bill raised under Calendar Wednesday could fall victim to delaying tactics by opponents. ${ }^{145}$ This was a threat to the Act because Calendar Wednesday proceeds alphabetically by "call of committee," so that the Judiciary Committee could have been the iwelfth committee to present a bill. ${ }^{156}$ Fearing that these procedural minefields would kill the civil rights bill, Democrats were forced to oppose the Republican suggestion to call up the bill on Calendar Wednesday. ${ }^{157}$ Republicans then attempted to use the Democratic vote against the motion to bring up H.R. 7152 on Calendar Wednesday ${ }^{158}$ politically: They argued that the vote indicated that Democrats were not truly pro-civil rights and that their accusations that Republicans were stalling the passage of legislation were in bad faith. ${ }^{159}$

149. WhaLEN \& WHALEN, supra note 99. al 84

150. LOEVY, supra note 99, at 91; see also discussion of discharge pettions supra text accompany ing notes $117-18$.

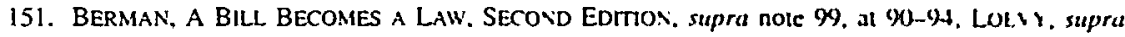
note 99 , at $92-95$.

152. H.R. DOC. No. 619, supra note 148. at 468-69 (Rule XXIV(7)). see also Rocise II Davidsol \& WALTER J. OleSZEK, CONGRESS AND ITS MEMBERS 275-76 (2d ed 1985). Tit:F:R, supra note I. al 336

153. LOEVY, supra note 99 , at 93.

154. H.R. DoC. No. 619. supra note 148. at 469-71 A wo-thurds vole could have overtone this requirement. Id.

155. HOW CONGRESS WORKS, supra note 18. at 56

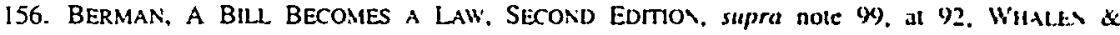
WHALEN, supra note 99 . at 85 . Thus if the 11 preceding committees used up most of the allotted ume, the Civil Rights Act might have been introduced with insufficient ume to consider It

157. Berman, A Bill BeCOMes a Law, SeCONd EdTION, supra note 99 , at 92

158. 109 CONG. REC. 24,217-18 (1963) (avolding Calendar Wednesday with vote to adjoum)

159. LOEVY, supra note 99, at 94: WHALEN \& WIIALEN, supra note 99. at 85 
This political battle continued until the threat of the third removal method broke the deadlock. House Rule XI(25) allows any three members of a committee to call for a meeting of that committee. ${ }^{160}$ If after seven days the committee has not yet met, a majority of the committee members may request that the clerk of the committee schedule a committee meeting immediately. ${ }^{161}$ When the Rules Committee's ranking Republican member Clarence J. Brown (R-Ohio) began to consider siding with liberal Democrats to use Rule XI to force Chairman Smith to begin hearings, Smith finally gave in. ${ }^{162}$ The hearings on H.R. 7152 began on January 9, $1964 .{ }^{163}$

The hearings before the Rules Committee lasted for the better part of a month, with twenty-nine Southern Representatives testifying before the Committee in opposition to the bill. ${ }^{164}$ Finally, when there were no further witnesses, Chairman Smith could hold off a vote on the bill no longer. On January 30, the Rules Committee reported H.R. 7152 out of committee ${ }^{165}$ by a vote of 11 to 4 , with only Southern Democrats opposing. ${ }^{166}$

The Rule proposed by the Rules Committee, H.R. Res. 616, was an open one allowing for no more than ten hours of general debate divided evenly between the majority and minority parties. ${ }^{167}$ H.R. Res. 616 passed the House of Representatives by voice vote on January $31,1964,{ }^{168}$ after which the House resolved itself into the Committee of the Whole. ${ }^{169}$ For ten days, the House debated the Civil Rights Act and consistently voted down weakening amendments proposed by Southern Democrats without procedural complications. ${ }^{170}$ Representatives Celler and McCulloch worked together to help ensure this success by creating a forceful whip system that herded liberal and moderate members to the floor for votes. ${ }^{171}$ On February 8, Rules Chairman Smith made one last effort to derail the bill by offering a controversial amendment that would add sex discrimination to the bill's proscribed acts. ${ }^{172}$ Contrary to his strategic expectations, the amendment

160. H.R. DoC. No. 619 , supra note 148 , at 363 .

161. Id.

162. WHALEN \& WHALEN, supra note 99, at 85-86.

163. Civil Rights: Hearings on H.R. 7152 Before the House Comm. on Rules, 88th Cong., 2d Scss., pt. 1, at I (1964).

164. See id. at III (listing Representatives who made statements); id. pt. 2, at III-IV (same).

165. 110 CONG. REC. D41 (1964).

166. See LOEVY, supra note 99 , at 99 (stating vote count).

167. 110 CONG. REC. 1511 (1964).

168. Id. at 1516 .

169. Id.

170. Id. at 1516-2805.

171. LOEVY, supra note 99, at 109-10; WHALEN \& WHALEN, supra note 99, at 108-09.

172. 110 CONG. REC. 2577 (1964); see also LOEVY, supra note 99, at 120; WHALEN \& WHALEN. supra note 99 , at 116. 
passed by a vote of 168 to $133^{173}$ but did not destroy the bill: On February 10, 1964, the House passed H.R. 7152 by a vote of 290 to $130 . .^{74}$

The next step for H.R. 7152 was the Senate and near-certain filibuster. During the October 1963 negotiations between Representative McCulloch and the Kennedy Department of Justice, the Administration had promised McCulloch that it would not play the legislative chambers against each other by allowing compromises with Senate Republicans that weakened the House bill, as it had done in 1957 and 1960. ${ }^{175}$ Therefore, despite President Johnson's concern that, as in 1960, it would be impossible to get the sixtyseven votes needed for cloture, the strategy of waiting, amending, and compromising under the general time allowances of Senate Rule XIX ${ }^{176}$ was not possible for H.R. 7152, because the liberal Senators' negotiating hands had been tied. ${ }^{177}$

On February 26, the Civil Rights Act was read for a second time on the Senate floor. ${ }^{178}$ Senate Majority Leader Mike Mansfield (D-Mont.) then took an unusual step: Instead of referring the bill to a committee, he made a motion to place the bill directly onto the Senate calendar. ${ }^{199}$ Numerous Senators objected, arguing that it was vital for a committee to examine the bill. ${ }^{1 \times 0}$ Nevertheless, Mansfield won the vote on his motion 54 to $37,{ }^{181}$ and the bill was placed on the Senate calendar, out of the reach of Senate Judiciary Committee Chairman Eastland.

Senator Mansfield planned to call up H.R. 7152 for Senate consideration on March 9. ${ }^{182}$ Under Senate Rule VII, in order to schedule consideration of the bill without debate on the issue of scheduling. Mansfield would have needed to advance the bill during "morning hour," a two-hour period at the start of the legislative day. ${ }^{183}$ Senator Richard B. Russell (D-Ga.) prevented this move, however, by taking up the whole two hours of "morning hour" on March 9 with a mini-filibuster. ${ }^{184}$ Mansfield's subsequent motion to call up

173. 110 CONG. REC. 2584 (1964).

174. Id. at 2804-05.

175. WHALEN \& WHALEN, supra note 99. at 13. 125.

176. Senate Rule XIX limited every Senator to two speeches per day on any one question in debate S. DoC. No. 1, 88th Cong., Ist Sess. 21 (1963) (Senate Manual). A Senate "Icgislauve day" can extend over many actual days. WHALEN \& WHALEN, supra note 99, at 129.

177. WHALEN \& WHALEN, supra note 99, at $129-30$

178. 110 CONG. REC. 3692 (1964).

179. Id. at 3692-93; see also WHALEN \& WHALEN, supra note 99, at 13.4

180. See 110 CONG. REC. 3711 (1964) (statement of Sen. Eastland) (arguing that this aeceleration of Senate procedure amounted to "legislative lynching"); see also id. at 3695 (statement of Sen Russell) (arguing that committee procedure was important for gathenng needed information), ud at 3710 (statement of Sen. Ervin) (arguing that Judiciary Committee would point out defects of bill)

181. Id. at 3719.

182. Id. at 4743 (including in record notice given by Sen. Mansfield of intention to call up H R. 7152)

183. S. DOC. No. 1, supra note 176, at 9 (allowing any Senator to lay before Senate any bill sent by House of Representatives; motion to do so "shall be determined without debate"), see also How COvGress WORKS, supra note 18, at 58 (explaining "morning hour").

184. 110 CONG. REC. 4743-54 (1964). 
H.R. $7152^{185}$ was thus subject to debate, and the bill's opponents began their first filibuster. ${ }^{186}$ It lasted until March 26 , when the Senate finally agreed, by a vote of 67 to 17 , to a motion allowing consideration of H.R. $7152 .{ }^{187}$ After Senator Wayne Morse (D-Or.) moved to send the bill to the Judiciary Committee, ${ }^{188}$ which motion the Senate defeated by agreeing to table it, ${ }^{189}$ the Senate was ready for the second filibuster-this time on the Civil Rights Act itself.

The second Senate filibuster began in late March and continued through the entire spring of $1964 .{ }^{190}$ The endless stalling slowly increased pressure on the Senators to vote for cloture. From April to mid-May, Senator Hubert H. Humphrey (D-Minn.)-the Democratic Whip and co-majority floor manager of H.R. 7152-negotiated possible compromises with Minority Leader Everett McKinley Dirksen (R-Ill.), Majority Leader Mansfield, and officials from the Department of Justice. ${ }^{191}$ As mentioned above, however, these negotiations were constrained by the Administration's promise to Representative McCulloch to keep the Senate bill close to the House version. ${ }^{192}$ The talks finally proved fruitful in mid-May, when Dirksen agreed to a compromise close enough to H.R. 7152 to be acceptable to McCulloch. ${ }^{193}$ In a press conference announcing the compromise, Dirksen declared that "[n]o army can withstand the strength of an idea whose time has come."194 The so-called "Dirksen substitute"195 was introduced in the Senate on May 26, 1964. ${ }^{196}$

On June 1, in the thirteenth week of the Senate filibuster, Majority Leader Mansfield declared that a cloture petition would be filed at the end of the week, with a vote on cloture scheduled for June $9 .{ }^{197}$ Supporters of the Civil

185. Id. at 4754 .

186. Id.

187. Id. at 6417 .

188. Id.

189. Id. at 6455

190. Senate consideration of H.R. 7152 lasted from March 9, id. at 4754, to June 19, id. at 14,511.

191. WHALEN \& WHALEN, supra note 99 , at $155-85$.

192. Id. at $125,156,181$; see also text accompanying notes $175-77$.

193. WhALEN \& WhALEN, supra note 99, at 183.

194. E.W. Kenworthy, Rights Bloc Wins Closure Support, N.Y. TIMEs, May 20, 1964, at Al, A34. Whalen and Whalen point out that Dirksen incorrectly attributed this phrase to Victor Hugo's diary. WHALEN \& WHALEN, supra note 99, at 185. The phrase is actually derived from Victor Hugo's Histoire d'un Crime, in which he wrote: "On résiste a l'invasion des armées; on ne résiste pas a l'invasion des idées." Victor Hugo, Histoire d'un Crime, in Victor Hugo Oeuvres COMPLEtes: HistoIRE 456 (Sheila Gaudon ed., Editions Robert Laffont 1987) (1877). For translation, see JOHN BARTLETT, FAMILIAR Quotations 491 \& 491 n.6 (Emily M. Beck ed., 15th ed., Little, Brown 1980) (1855) ("An invasion of armies can be resisted, but not an idea whose time has come."). For additional coverage of Dirkscn's position, see E.W. Kenworthy, Rights Plan Goes to Senate Today, N.Y. TIMES, May 26, 1964, at A27 (describing Dirksen press conference).

195. WHALEN \& WHALEN, supra note 99, at 188.

196. 110 CONG. REC. 11,897 (1964); see also WHALEN \& WHALEN, supra note 99, at 188.

197. 110 CONG. REC. 12,274-76 (1964); see also WHALEN \& WHALEN, supra note 99, at 190. 
Rights Act then engaged in a "counter-filibuster"198 throughout the week, in order to "'nail down those cloture votes."'199 The cloture petition was filed on June $8,{ }^{200}$ with a vote scheduled for Wednesday, June $10 .^{201}$ The filibuster came to an end as Senator Robert Byrd (D-W. Va.) held the floor from 7:38 p.m. on June 9 until 9:51 a.m. on the morning of June 10. ${ }^{202}$ The Senate then voted on cloture; the petition passed by a vote of 71 to $29 .^{203}$

Senate rules allowed each member to speak for one hour following cloture. ${ }^{204}$ Additional amendments proposed by resistant Southern Senators were voted upon during that time, almost all of which were defeated. ${ }^{205}$ On June 17, the Dirksen substitute passed the Senate by a vote of 76 to $18 .^{206}$ On June 19, after a failed final attempt to refer H.R. 7152 to the Judiciary Committee, ${ }^{207}$ the Senate at last voted on final passage: The bill passed by a vote of 73 to $27 . .^{208}$

On June 22, the Senate reported the passage of H.R. 7152 to the House of Representatives. ${ }^{209}$ Representative Celler immediately endorsed the Senate version of the bill, and asked the House to agree to it unanimously. ${ }^{210}$ Four Representatives objected. ${ }^{211}$ For this reason, under normal House procedure, the bill had to be sent back to the Rules Committee and Chairman Smith. ${ }^{212}$ In response to this situation, an internal White House memo to President Johnson from Larry O'Brien, special assistant to the President, stated that "[w]e must assume that Howard Smith will delay as long as possible on granting a rule." 213 The memo described two options for avoiding Chairman Smith. The first possibility called for applying House Rule XI. ${ }^{21}$ The second

198. 110 CONG. REC. 12,642 (1964) (statement of Sen. Russell).

199. WhALEN \& WHALEN, supra note 99 . at 190 (quoung Sen Huber Humphrey)

200. 110 CONG. REC. 12.922 (1964).

201. Id. at 12,923 .

202. Id. at $13,133-219$.

203. Id. at 13,327 .

204. S. DoC. No. 1, supra note 176, at 24 (Senate Rule XXII(2) forbids any Senator to speak more than one hour post-cloture).

205. See, e.g., 110 CONG. REC. D267, D269, D272-73, D277-79 (1964) (Itsung amendments proposed by Senators Byrd, Cooper, Eastland. Ervin. Gore, Long. McClellan. Russell. Sparkman. Siennis, Thumond, and Tower).

206. Id. at 14,239 .

207. Id. at 14,442; see also id. at 14,433 (text of Senator Gore's motion to refer bill to Judiciary Committee).

208. Id. at 14,511 .

209. Id. at $14,630-31$.

210. Id. at 14,631; see also E.W. Kenworthy. Civl Rights Bill Passed, 73-27. N.Y. TIMiEs. June 20. 1964, at Al (quoting endorsement of Senate version of bill by Representatuves Celler and MeCulloch)

211. 110 CONG. REC. 14,631 (1964).

212. Edward F. Willett, JR., How OUR Laws ARE MAde, H.R. DOC No. 158. 99ih Cong.. 2d Sess 37 (1986): see also WHALEN \& WHALEN, supra note 99. at 219. See generally HOW CONGRESS WORKS, supra note 18, at 63 (describing acceptance of bill by second chamber).

213. Memorandum from Lawrence F. O'Brien to President Johnson (June 18, 1964), in 13 CiviL. RIGHTS. THE WHITE HOUSE. AND THE JUSTICE DEPARTMENT. 1945-1968, at 165-66 (Michal R. Belknap ed., 1991) [hereinafter CIVIL RIGHTS 1945-1968].

214. Id.; see also WHALEN \& WHALEN, supra note 99. al 219-20 (discussing Rule XI option), supra text accompanying note 160 (discussing House Rule XI). 
option was to proceed under "suspension of rules," which would allow for only forty minutes of debate on the bill, ${ }^{215}$ but would require the support of twothirds of the House for its suspension. ${ }^{216}$ The next possible date for rules suspension was July 6, which was inconvenient for Republican members because it was extremely close to the date of the Republican convention. ${ }^{217}$ Representatives Celler and McCulloch therefore chose the first option, placing H.R. Res. 789, a resolution "to provide for the concurrence of the House of Representatives to the Senate amendment to H.R. 7152,"218 in the hopper ${ }^{219}$ on Monday, June $22 .{ }^{220}$ H.R. Res. 789 was immediately referred to the Rules Committee, ${ }^{221}$ and on June 24, three Representatives filed a formal Rule XI request for the Rules Committee to hear the resolution. ${ }^{222}$ A June 25 letter to President Johnson from advisor Jack Valenti stated that "Judge Smith is not opposed to giving a rule. But he insisted that any Congressmen who wanted to testify would be allowed to do so."223 The committee members voted 7 to 4 to conduct all hearings in one day, ${ }^{224}$ however, and then voted 10 to 5 to grant a Rule for H.R. Res. 789 that allowed only one hour of debate and required that the bill be immediately reported to the House. ${ }^{225}$ Furthermore, the committee members went so far as to invoke a committee rule permitting any committee member to report a Rule to the House if the chair refuses to do so, effectively stripping the bill away from Chairman Smith. ${ }^{226}$

On June 30, the House Rules Committee reported H.R. 7152 back to the House floor. ${ }^{227}$ The drama finally came to an end on July 2, 1964, when the House voted 289 to 126 in support of H.R. Res. 789, thus agreeing to all Senate changes to H.R. $7152 .{ }^{228}$ The bill had passed both chambers; President Johnson signed it into law that night. ${ }^{229}$

215. H.R. DoC. No. 619 , supra note 148 , at 477 .

216. Id. at 474-75; see also CIVIL RIGHTS 1945-1968, supra note 213, at 166.

217. WHALEN \& WHALEN, supra note 99, at 219; see also id. at 159 (citing Senator Dirksen's desire to avoid forcing Congress to return to Washington after Republican convention).

218. 110 CONG. REC. 14,672 (1964). For text of H.R. Res. 789 , see id. at 15,869 .

219. The hopper is a box at the side of the clerk's desk. TIEFER, supra note 1, at 33.

220. 110 CONG. REC. 14,672 (1964); WHALEN \& WHALEN, supra note 99, at 220.

221. 110 CONG. REC. 14,672 (1964).

222. LOEVY, supra note 99, at 307-08; WHALEN \& WHALEN, supra note 99, at 220; see also supra text accompanying note 160 .

223. Letter from Jack Valenti to President Johnson (June 25, 1964), in CiVIL RightS 1945-1968, supra note 213 , at 167 .

224. WHALEN \& WHALEN, supra note 99, at 220-22 (citing transcripts of closed executive session of Rules Committee on file at National Archives).

225. Id. at 222 (same); see also LOEVY, supra note 99, at 307-08.

226. WHALEN \& WHALEN, supra note 99, at 222-23 (citing transcripts of closed executive session of Rules Committee on file at National Archives); see also LOEVY, supra note 99, at 307-08.

227. H.R. REP. NO. 1527, 88th Cong., 2d Sess. 1 (1964).

228. 110 CONG. REC. 15,897 (1964). For text of H.R. Res. 789 , see id. at 15,869 .

229. Radio and Television Remarks upon Signing the Civil Rights Bill, 1963-64 PUB. PAPERS 842-44 (July 2, 1964); 110 CONG. REC. D513 (1964). 


\section{The Impact of Congressional Procedure Reforms}

With the procedural histories of the Civil Rights Acts of 1960,1964, and 1991 as a backdrop, this Note now examines whether congressional procedural reforms had an identifiable impact on the passage of the Civil Rights Act of 1991. This analysis does not attempt to demonstrate a simple cause-and-effect relationship between the reforms of the 1970's and the passage of the 1991 Civil Rights Act; far too many other factors affect the legislative process to enable such an approach. Nevertheless, this Part illuminates the fingerprints of prior congressional reforms on the 1991 legislative process.

\section{A. Reforms of Seniority Rules and Committee Leadership}

The largest obstacles that confronted the 1960 and 1964 Civil Rights Acts were committee chairs who wielded their disproportionate power to block the bills' progress. ${ }^{230}$ These Southern Democratic chairs opposed civil rights legislation, and although they held their leadership positions because of the Democratic majority in both chambers of Congress, on civil rights issues they worked against the majority of those Democratic members by consistently joining Republicans to block legislation.

Unsurprisingly, most Democratic members responded to this situation with reforms that diminished the control of committee chairs over the legislative agenda. As David Rohde states in Parties and Leaders in the Postreform House, newly elected liberal members of that era "found institutional arrangements (especially the disproportionate powers of committee chairmen) to be biased against their interests and in favor of those of the "conservative coalition.' They sought to redress the institutional imbalance through the reforms of the 1970's, which weakened chairmen and strengthened the majority party."231 These reforms also redistributed power among more members of Congress, so that the Democratic congressional leadership became more disparate and more representative of its membership.

The passage of the 1991 Civil Rights Act demonstrates the importance of these reforms. Rather than fighting the Democratic leadership, 1991 subcommittee and committee chairs worked with it to pass their common legislative agenda. Although the voting patterns of the conservative coalition remained unchanged, the Democratic majority was no longer held its captive. ${ }^{232}$

230. See supra part II.

231. David W. Rohde, Parties and Leaders in the Postreform hol SE 162 (1991)

232. The conservative coalition did still exist as a voung bloc. however. and greatly increased the difficulty of passing the 1991 Act. For example, the bloc prevented House passage of H.R 1 by the twothirds needed to render a presidential veto inconsequentral. See supra text accompanying notes 57-58 
When the Civil Rights Acts of 1960 and 1964 were before Congress, they faced a body steeped in tradition, particularly the influential tradition of committee leadership by seniority. As Tiefer explains, before the 1970's, "the iron rule of seniority made selection of the most senior Member as chair automatic. $" 233$ In $1964,95 \%$ of all House committees were chaired by their most senior members; in the Senate, that figure was $100 \% .{ }^{234}$

Despite their facial neutrality, congressional seniority rules produced an observable political bias in both chambers in the early 1960's. Given the relative volatility of Northern Democratic congressional seats compared to Southern ones, Southern Democrats were disproportionately represented among the most senior members of Congress and thus dominated the leadership of most congressional committees. ${ }^{235}$ As documented by Mack C. Shelley II, in $1960,63 \%$ of Senate committees and $65 \%$ of House committees were chaired by Southern Democrats; in 1964, the respective figures were $63 \%$ and $60 \%{ }^{236}$ Indeed, Shelley's data reveal percentages of comparable magnitude for several consecutive decades. ${ }^{237}$ This disproportionate power distribution survived into the mid-1970's; in 1974, the numbers were $47 \%$ and $43 \%$, respectively. ${ }^{238}$

Congressional reforms of the 1970's altered both the seniority system and the appointment of committee leadership. ${ }^{239}$ Reforms in the House of Representatives were originally rooted in the actions of discontented liberal members of Congress, who began meeting in the mid-1950's and formed the House Democratic Study Group in $1959 .{ }^{240}$ After examining the voting

233. TIEFER, supra note 1 , at 102.

234. The Senate figure includes committees chaired by their second-most-senior member if the most senior member had waived his or her seniority. Figures calculated by author from data compiled in 20 CONG. Q. AlmaNAC 27-32 (1964) (listing members by seniority); id. at 39-59 (listing committee membership); id. at 39 (example of notation used to indicate seniority waiver).

235. GEORGE B. Galloway, History OF THE HOUSE OF REPRESENTATIVES 83 (1976) (analyzing regional distribution of chairships); SHELLEY, supra note 4, at 67 (documenting "the classic era of committee dominance by senior Southerners protected by uncompetitive elections and generally not answerable to the official party leadership"); TIEFER, supra note 1, at 102 (noting that senior conservative Southern Democrats dominated committee chairships).

236. SHELLEY, supra note 4 , at 66 .

237. Id. at $66-67$.

238. Id. at 67 . Other authors have replicated these data with some variation in results. For example, Shelley found Southern committee leadership percentages of $47 \%$ and $43 \%$ in 1973, id., but Roger H. Davidson states that, in 1973. "Southemers composed less than $30 \%$ of congressional Democrats, yct commanded 46 percent of House full-committee chairmanships and 53\% of those in the Senate," Roger H. Davidson, Subcommittee Government: New Channels for Policy Making, in THE NEW CONGRESs 99. 106 (Thomas E. Mann \& Norman J. Ornstein eds., 1981).

239. Prior to the 1970's, there had been some effort to diminish the importance of seniority. For example, in 1953, the Senate Democratic Steering Committee approved what came to be known as the "Johnson Rule," named for Senator Lyndon B. Johnson, which required that every Democratic Senator be given a seat on one major committee before any could get a seat on a second major committec. How CONGRESS WORKS, supra note 18, at 110; see also SMITH \& DEERING, supra note 1, at 30 . The Senate Republican Conference made the same rule change in 1965. How CONGRESS WORKS, supra note 18, at 110 .

240. See Mark F. Ferber, The Formation of the Democratic Study Group, in CONGRESSIONAL BeHAvior 249, 249-54 (Nelson W. Polsby ed., 1971). 
patterns of House members and especially House committee chairs, the House Democratic Study Group began to initiate changes that would "create a situation in which liberal policy proposals would win more often."

The reforms began with the Legislative Reorganization Act of 1970.24 The Act first limited the use of proxy voting in committees in both the House and the Senate, ${ }^{243}$ which decreased the ability of committee chairs to wield disproportionate power during votes. ${ }^{244}$ The $1970 \mathrm{Act}$ also required recorded teller votes in the House Committee of the Whole during the amendment process upon the request of one-fifth of a quorum, ${ }^{245}$ and mandated that House and Senate committee roll-call votes be recorded in the committec reports. ${ }^{246}$ In addition, the 1970 Act significantly limited the power of senior Senators, who were restricted to membership on only two major and one minor committee and allowed to chair no more than one full committee and one subcommittee of a major committee. ${ }^{247}$

Congressional reconfiguration continued through intraparty reforms. Democratic Caucus reforms on January 20, 1971, stipulated that the House Democratic Committee on Committees would nominate committee chairs, that nominees need not be the most senior committee members, that the nominees

241. ROHDE, supra note 231, at 19.

242. Pub. L. No. 91-510. 84 Stat. 1140 (codified as amended in scattered sections of 2 I' S C. 31 U.S.C.. \& 40 U.S.C. (1988 \& Supp. V 1993)). This measure "as "passed by a coalution of (1wo groups of outsiders (House Republicans and liberal Democrats)." Luurence C Dodd \& Buce I Oppenhemer, The House in Transitıon, in CONGRESS RECONSIDERED 21. 26-27 (Lawrence C. Dodd \& Bruce I Oppenheimer eds., 1977). Section 101 of the Legislative Reorganizatıon Act reserves for both chambers the option to change their rules at any time, based on their constitutional authonty to determine their rules of procecding U.S. CONST. art. I, $\$ 5$, cl. 2.

243. Pub. L. No. 91-510. \$106. 84 Stat. at 1146; Firsi Congressional Reform Bill Enacted Since 1466. 26 CONG. Q. ALMANAC 447 (1970) (describing Act).

244. Although this Note focuses on reforms that remained intact in 1991, not all of the reforms of the 1970's have lasted up to the present day. Proxy voling. a process that increases the pouce of commitice chairs by allowing them to hold and cast the votes of absent commutte members, was one such reform Currently, voting by proxy is not allowed on the floors of ether the House or the Senate. but untul the beginning of the 104th Congress, it was allowed in the commutees of both chanber llow Covcriss WORKS, supra note 18. at 92. The 1970 Legislative Reorganization Act stnctly curtalled proxy voung. prohibiting the practice unless committee rules specifically sanctioned 1 , in which case the proxies had to be limited to a specific issue and authorized in writing. Id. In 1974. the House soted to ban proxy soung altogether, but this prohibition was revised in 1975 to allow once agaun commuttces to permut the use of specific proxies. H.R. DOC. No. 416. 93d Cong.. 2d Sess. 420-21 (1975) (House Manual), ser also RL LeS

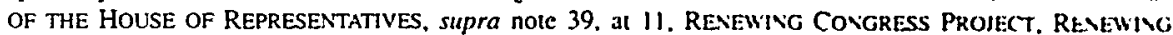
CONGRESS: A FIRST REPORT 40 (1992) [hereinafter RENEWING COVGRESS] The Senate has sumular rules. leaving regulation of proxies to individual commitees. S DOC No. I. supra notc 77. at 55 . see also TIEFER, supra note 1, at 173. Led by Speaker Newt Gingnch (R-Ga.), the Republican-controlled House of the 104th Congress voted to ban proxy voting in committee on January 4. 1995 Kenneth J Cooper \& Helen Dewar, Passing the Torch on Captrol Hill. WASH. POST. Jan 5. 1995. at Al (describing House rule changes).

245. Pub. L. No. $91-510 . \$ 120.84$ Stat. at 1157

246. Id. \$ 104, 84 Stat. at 1145; see also First Congressional Reform Bull Enacied Stute /4h6, supra note 243, at $448-49$ (describing 1970 reforms).

247. Pub. L. No. 91-510. \$132(d)(6)(a)-(g). 84 Stat. at 1165-67. see also S Dox No 1. supra note 77, at 37-39 (Rule XXV on committee membership): First Congressional Reform Bull Enatied Since 1446. supra note 243. at 450 . 
would be recommended individually instead of as a slate, and that the Caucus would debate and vote on any nomination at the request of ten committee members. ${ }^{248}$ The 1971 changes included two other provisions that directly diminished the power of House committee chairs: (1) a rule limiting subcommittee chairships to one per member, thus opening up leadership positions for more junior members, ${ }^{249}$ and (2) a rule allowing subcommittee chairs to hire one staff member each, rather than leaving all hiring in the hands of the full committee chair. ${ }^{250}$ Republican House members enacted reforms similar to those of the Democrats on the same day, allowing their chairs or ranking minority members on each committee to be selected not strictly by seniority but by a secret ballot vote of the Republican Conference. ${ }^{251}$

In 1973, the House Democratic Caucus ratified yet another round of reforms. ${ }^{252}$ These included: (1) automatic Caucus votes on committee chairs, by secret ballot if demanded by twenty percent of the Caucus; ${ }^{253}$ (2) the creation of a new Steering and Policy Committee within the Caucus to consider party policy positions; and (3) the "Subcommittee Bill of Rights," which guaranteed subcommittee jurisdiction, referral of legislation to subcommittees, and votes on nominees for subcommittee chairs in order of seniority. ${ }^{254}$ These reforms all decreased the power of committee chairs and increased the autonomy and power of subcommittee chairs. ${ }^{255}$ Senate Republican reforms followed the same trend: In 1973 the Republican Caucus agreed that the Republicans on each committee would nominate their ranking members. ${ }^{256}$

In 1974, the House Democratic Caucus reassigned the responsibility for committee chair nominations from the Democratic Committee on Committees (composed of the House Speaker and the Democratic members of the Ways and Means Committee) to a Democratic Steering and Policy Committee elected

248. Seniority System Challenged in Both Houses, 27 CoNG. Q. ALMANAC 17, 17 (1971) [hereinafter Seniority System]. The 1971 reforms grew out of recommendations by the Democratic Caucus' Committec on Organization Study and Review, better known as the Hansen Committee, named for its Chair, Representative Julia Hansen (D-Wash.). Id.; see also SMITH \& DEERING, supra note 1, at 44.

249. LeRoY N. Rieselbach, CONGRESSIONAL ReForm IN THE SEventies 45 (1977); see also Seniority System, supra note 248, at 17.

250. See RoHDE, supra note 231, at 21; SMITH \& DEERING, supra note 1, at 44.

251. See Dodd \& Oppenheimer, supra note 242, at 29; Seniority System, supra note 248 , at $17,19$.

252. See RIESELBACH, supra note 249 , at 45 ; SMITH \& DEERING, supra note 1 , at $44-45$.

253. Seniority Rule: Change in Procedure, Not in Practice, 31 CoNG. Q. WKLY. REP. 136, 137 (1973).

254. SMITH \& DEERING, supra note 1, at 44-45. The 1973 reforms also included procedures intended to prevent the use of closed rules to stifle debate on Ways and Means bills. Dodd \& Oppenheimer, supra note 242 , at $29-30$.

255. See How CONGRESS WORKS, supra note 18, at 101; Dodd \& Oppenheimer, supra note 242, at 39.

256. TIEFER, supra note 1, at 104. Tiefer points out, however, that when Republican members of the Senate Foreign Relations Committee voted Senator Richard Lugar (R-Ind.) their ranking minority member in 1987, the Republican Caucus overruled that vote and strictly followed seniority, naming Senator Jesse Helms the ranking minority member. Id. 
by all Democratic members. ${ }^{257}$ The Caucus, however, reserved for itself the power to reject nominations made by the Steering and Policy Committee. ${ }^{288}$ Finally, in 1975, the Senate Democratic Caucus followed earlier House reforms, agreeing to secret ballot votes on committee chairs if twenty percent of the Democratic Senators so requested. ${ }^{259}$

\section{B. Effects of the Reforms of Seniority Rules and Committee Leadership}

The immediate impact of the 1970's reforms on congressional behavior was significant. After the Democratic Caucus had tested the power of the reforms by unseating three committee chairs in 1974, one junior House member reported that freshman members had reason to believe that senior committee leaders could no longer afford to ignore their concerns. ${ }^{360}$ In addition, Richard P. Conlon, staff director of the Democratic Study Group, asserted in 1972 that the reform instituting recorded teller votes in the Committee of the Whole had forced chairs to consider the opinions of "the entire membership of the House," rather than merely those of the more conservative members of the Committee of the Whole. ${ }^{261}$ Similarly, Congressional Quarterly Inc. summed up the new relationship by stating that "[t]he key to the power of the Democratic Caucus remained its authority to select committee chairmen. When the Caucus 'urged' a committee to take action, the assumption was that the chairman would heed the recommendation, or face the consequences."262

In addition to more responsive leadership, one of the most obvious effects of the decade's reforms was the change in the leadership's composition. Whereas Southern Democrats had chaired upwards of $60 \%$ of all committees in the 1960 's, ${ }^{263}$ by 1979 , they chaired only $20 \%$ of Senate committees and only $27 \%$ of House committees. ${ }^{264}$ This trend has continued to the present: In the $102 \mathrm{~d}$ Congress, only $34 \%$ of all committee chairs were Southerners. ${ }^{205}$

257. DAVIDSON \& OLESZEK, supra note 152, at 218: TIEFER. supra note 1, al 94. See generally PReamble and Rules of the Democratic Caucus. 101ST CONG., IST Sess. 7-11 (1989) [hereinafter DEMOCRATIC CAUCUS RULES] (outlining caucus rules for committee membership and chairs)

258. See How CONGRESS WORKS. supra note 18, at 111: Dodd \& Oppenheimer, supra note 242, at 31. The 1974 reforms also included changes concerning the House Appropnations Committee. Id. al 31 . see also RIESELBACH, supra note 249, at 45. For a compilation of all the Democratic Caucus rules, see DemoCRATIC CauCUS RULES, supra note 257.

259. TIEFER, supra note 1 , at $104-05$.

260. See id. at 103-04 (quoting unnamed member in CONGRESS OFF TIE RECORD THE CANDID ANALYSES OF SEVEN MEMBERS 8-9 (John F. Bibby ed.. 1983)).

261. See Legislative Reorganization Act: First Year's Record. 30 CoNG. Q. WXLY REP 485. 488 (1972) (quoting Conlon).

262. HOW CONGRESS WORKS. supra note 18. at 21: see also SMITI \& DEERING, supra note 1, at \& (stating that 1971 reforms "limited the full committee chaırs" abulity to dominate their committees")

263. See supra text accompanying note 236.

264. SHELLEY, supra note 4, at 67.

265. The author calculated these figures from data compiled in 47 CONG Q AL4ANAC 23D-6ID (1991) (listing committee membership). 
In addition, the percentage of majority members who were committee or subcommittee chairs grew from $27.2 \%$ in the House and $87.5 \%$ in the Senate in 1955 to $52.2 \%$ in the House and $98.3 \%$ in the Senate in $1981{ }^{266}$ This trend has also continued to the present day; today half of the members of the House Democratic Caucus are subcommittee chairs. ${ }^{267}$ As Professors Dodd and Oppenheimer assert, "the reforms of the 1970-1975 period [were] the key in guaranteeing subcommittee influence in the House," since those reforms mandated a minimum of sixteen new subcommittee chairs. ${ }^{268}$ The reforms not only changed the composition of congressional leadership ${ }^{269}$ but also democratized that leadership through forced redistribution of leadership positions.

Moreover, these procedural reforms altered the way congressional leadership controlled the legislative agenda. This change is most evident in the case of the House Rules Committee and its obstructionist role in 1960 and 1964 compared to its role in 1991 . The House Rules Committee had been the subject of procedural reforms before the changes of the early 1970's detailed above. ${ }^{270}$ In addition, in 1975, the House Democratic Caucus adopted a Caucus rule giving the House Speaker the power to appoint the chair and Democratic members of the Rules Committee, subject to ratification by the

266. SMITH \& DEERING, supra note 1 , at 51.

267. RENEWING CONGRESS, supra note 244 , at 32.

268. Dodd \& Oppenheimer, supra note 242 , at 35.

269. Although the causes of the changes in congressional leadership have been researched extensively, a thorough presentation of the contributing factors is beyond the scope of this Note. Analyses of demographic shifts in congressional leadership demonstrate persuasively that fluctuations in the volatility of seats in different regions of the country, in addition to the increased strength of the Republican party in the South, have played an important role in diminishing Southern dominance over committee leadership since the 1970's. See, e.g., ORFIELD, supra note 137, at 7, 11, 29-34 (attributing decline of Southern committee leadership to lost safe seats due to urbanization and Republican challenges in South and arguing that seniority is not inherently conservative but inherently biased in favor of those whose seats are safest); SHELLEY, supra note 4, at 68,72 (acknowledging demographic changes due to increased Southern electoral competitiveness and emerging Northern safe seats); TIEFER, supra note 1, at 104 (noting rise of primary elections and increasing Republican power in South); see also GALLOWAY, supra note 235, at 83 (analyzing regional distribution of chairs). Even when discussing demographic changes, however, these studies acknowledge the important impact of congressional procedural reforms on the composition of committee leadership. See RENEWING CONGRESS, supra note 244, at 13 (describing how 1970's reforms strengthened House Speaker); RIESELBACH, supra note 249, at 43-47 (asserting that "democratizing reforms" of 1970's gave more members "a piece of the action"); SHELLEY, supra note 4, at 68 (noting influence of 1970's reforms); SMITH \& DEERING, supra note 1, at 35-57 (same).

270. In 1961, for instance, Speaker Sam Rayburn (D-Tex.) expanded the Rules Committee in order to increase the membership of pro-leadership, liberal Democrats. See discussion supra note 148 and accompanying text. In addition, after the 1964 election produced a new, more liberal, Democratic majority in the House, the Democrats enacted a "21-day rule" that empowered the chair of any committec that had reported a bill to the Rules Committee to introduce that bill onto the House floor if it had faced 21 days of Rules Committee delay and if the Speaker recognized the member. How CONGRESS WORKS, supra notc 18. at 56-57; ORFIELD, supra note 137, at 36. The 21-day rule was repealed, however, when liberal House Democrats lost their majority to more conservative Democrats in the 1966 elections. How ConGRESS WORKS, supra note 18, at 56-57; ORFIELD, supra note 137, at 36 . An attempt in 1971 to reinstate the rulc failed. ORFIELD, supra note 137 , at 36 . 
Caucus. ${ }^{271}$ According to many authors, this change brought the Rules Committee more firmly under the command of House leadership and "loosened the conservative coalition's grip on the panel." ${ }^{.772}$ Upon receiving the right to appoint members to the Rules Committee, Speaker Carl Albert (D-Okla.) chose two strong liberals to fill the open positions. One of those appointees was freshman Representative John Joseph (Joe) Moakley of Massachusetts." who was to become Rules Committee Chairman in 1989 $9^{274}$ and chair the Committee during the passage of the 199l Civil Rights Act.

The procedural histories recounted in Parts I and II of this Note illustrate the ways Rules Committee Chairman Howard Smith worked to obstruct and delay civil rights legislation in the 1960's. In 1960 and 1964, Representatives who supported civil rights legislation struggled repeatedly to force the Rules Committee to relinquish control over the Civil Rights Acts and allow them onto the House floor. In February of 1960, Chairman Smith refused to hold hearings on H.R. 8601 until the names on a discharge petition grew so numerous that it became clear the bill might be forcefully discharged from his purview. ${ }^{275}$ In autumn of 1963, Chairman Smith was again the key obstacle to civil rights legislation: His refusal to write a Rule for the civil rights bill precipitated the struggle between the Democrats' discharge petition and Republican efforts to call up the bill during Calendar Wednesday proceedings. ${ }^{276}$ Then, in June 1964 , after the bill had finally passed the Senate, Chairman Smith delayed it once again, until a Rule XI request forced him to hold hearings. ${ }^{277}$ Furthermore, even though Smith was forced to allow the civil rights bills through the committees, the Rules that emerged for both the 1960 bill (H.R. Res. 359) 278 $^{27}$ and the 1964 bill (H.R. Res. 616) ${ }^{27 \%}$ were open: They allowed ten to fifteen hours of general debate and unlimited germane amendments. These open Rules led to lengthy debate, numerous amendments, and slower passage of the bills.

In contrast, the 1991 Rules Committee worked hand in hand with the Democratic leadership to pass the Civil Rights Act; Chairman Moakley twice

271. DAVIDSON \& OLESZEK, supra note 152, at 273: ROHDE supra notc 231, at 98, TIt:11.R, supra note 1, at 259-60; see Democratic Caucus Rules, supra note 257, at 4

272. DAVIDSON \& OLESZEK, supra note 152. at 273. Tiefer desenbes the behasior of the Rules Committee as "obstructing on behalf of the conservative coaltion" until "The majonty party gradually cut back the Rules Committee's independence." TIEFER, supra note I. at 259-60 The postreform commuttce then became an "arm of the leadership." How CONGRESS WORKS. supro note 18, at 96-97, ske also GallowaY, supra note 235, at 69 (stating that 1974 Democratic Caucus change allowing Speaker to nominate Democratic Rules Committee members "sufggests that the Democrats have chosen to strengthen the role of the leadership and party government in its relationshup with (the Rules Clommuttec")

273. RIESELBACH, supra note 249, at 57.

274. Chuck Alston, A Nuts-and-Bolts Democrat, 47 CONG. Q. WhLY REP 1305. 1305 (1989)

275. See supra text accompanying note 121 .

276. See supra text accompanying note 151 .

277. See supra text accompanying note 222.

278. See supra text accompanying note 125.

279. See supra text accompanying note 167. 
used the Rules Committee to hasten House passage of the Civil Rights Act of 1991. First, in shaping the Rule for the original consideration of H.R. 1, Moakley assured the success of the bipartisan Brooks-Fish compromise by allowing only three hours of debate and three amendments in a prescribed "King of the Hill" order. ${ }^{280}$ Second, when the 1991 bill returned to the House, Moakley ignored liberal Democratic criticism of the Wards Cove exemption and wrote a totally closed Rule that allowed no amendment or alteration. ${ }^{281}$ Chairman Moakley's use of the Rules Committee, of which he was a member due to its expansion in $1961,{ }^{282}$ indicated that changes in congressional procedure had the tangible effect of bringing the Committee more in line with the views of the majority of Democratic members. As envisioned by the 1975 reformers, the 1991 Rules Committee functioned as a tool of House leadership, easing and speeding legislative passage of liberal measures.

Other aspects of the legislative passages of the 1960 and 1964 Civil Rights Acts also demonstrate the importance of the procedural reforms of the 1970's. Neither the 1960 nor the 1964 bills, for example, were based on versions that originated in the Senate, because Senator Eastland's Judiciary Committee was totally unresponsive to the interests of liberal Democratic Senators. Civil rights legislation was ultimately successful only because Chairman Celler supported it and was willing to use his House Judiciary Committee to that effect. ${ }^{283}$ If the 1975 reform allowing secret ballot votes on Senate committee chairs had been in place already, Eastland might have been forced to respond to the concerns of other Democratic Senators, rather than allowed to side so readily with Republicans. In addition, the shape of the entire 1991 Democratic leadership could be considered a product of the reforms of the 1970's: Because of the limits on the number of chairs members could hold, more 1991 members were senior members and leaders of committees and subcommittees. The fact that the passage of the 1991 Civil Rights Act was eased by a Democratic leadership much closer ideologically to the wishes of the majority of Democratic members demonstrates the effect of this redistribution of power.

\section{Changes in Senate Cloture Procedures}

Another aspect of congressional procedure that has been the subject of numerous reforms is the Senate cloture rule, Senate Rule XXII. ${ }^{284}$ The history of the passage of the 1964 Civil Rights Act leaves no doubt that

280. See supra text accompanying note 35 .

281. See supra text accompanying note 92.

282. See supra notes $148,273-74$ and accompanying text.

283. See supra text accompanying note 140.

284. See supra note 112 and accompanying text. 
cloture was an essential tool in moving civil rights legislation forward to a vote. ${ }^{285}$ In 1963, six Senators, including Senator Humphrey, wrote to President Kennedy that:

The current proposals to modify Senate Rule XXII are. of course, directly related to the Democratic record on civil rights in the 88th Congress. . . . Since more than 60 percent of the Senators have supported cloture on FEPC legislation on two occasions in the postwar period, the modification of Rule XXII to permit three-fifths cloture is of obvious importance. ${ }^{286}$

One scholar has also noted the conservative bias of the filibuster, which frequently works to prevent or postpone liberal policy initiatives. ${ }^{287}$ The Civil Rights Acts of 1960 and 1964 provide examples of this conservative tendency. Filibusters were the Senate's tool of choice for blocking civil rights legislation: The 1960 Senate bill was stalled by failure to reach the two-thirds needed for cloture, ${ }^{288}$ and the 1964 bill faced two long filibusters, first on the issue of whether even to consider the bill, ${ }^{289}$ and then on the bill itself. ${ }^{290}$

Despite efforts at reform in 1969 and 1971,,$^{291}$ cloture rule changes did not take place until 1975, when the Senate finally decreased the votes needed for cloture from two-thirds ${ }^{292}$ to three-fifths of the entire Senate membership. ${ }^{293}$ Further reforms in 1979 placed a one-hundred-hour cap on

285. See text accompanying notes 182-208; see also CIviL RiGirTs 19.45-1968, supra note 213, at 33 (memorandum from Senate Majority Leader Mansfield to President Kennedy (June 18, 1963)) ("In present circumstances, there is only one practicable way in which lpassage of as much of the Administralion's legislative proposals on civil rights as possiblel can be assured, by counung 67 votes on cloture for whatever bill is pushed.").

286. Civil RIGHTS 1945-1968, supra note 213. at 15 (letter from six Democratue Senalors to President Kennedy (Jan. 8, 1963)).

287. ORFELD, supra note 137, at 44 (stating that filibuster rule usually biases legislatuve process against liberal attempts to change status quo). It could be argued that the role of the filibuster as a conservative tool against liberal initiatives has simply been a function of the near-contınuous minonty status of the Republican party in the Senate in recent decades. Because they were in the minonty. Republicans and conservative Democrats used the filibuster as their only consistently potent weapon aganst a more liberal agenda. Thus, it might be argued that we should now expect to see the filibuster become the tool of liberal Democrats, as they rely on it to block conservative inuatuves of the Republican majonty in the 104th Congress. This argument can support Orfield"s assertion. however, if one uses the term conservalıve not so much to denote political party, but rather in its more essentual sense-as conserving the status quo If Democrats of the 104th Congress use the filibuster aganst the Republican majonty. they will probably be doing so in order to preserve the current status quo from the proposed changes of the Republicans" "Contract with America." Thus, the filibuster will still be used as a means of blocking legislation by those who wish to preserve the status quo.

288. See supra text accompanying note 115.

289. See supra text accompanying note 187

290. See supra note 190.

291. ORFELD, supra note 137, at 41: see also Senate Agann Rejects Change in Filbuster Rule, 27 Cong. Q. Almanac 13, 13 (1971). (1980).

292. See supra note 112 and accompanying text; see also MICHAEl. Foley. THE New SExATE 29

293. See supra note 112. 
all action on a bill after cloture has been invoked, in order to eliminate postcloture filibusters; ${ }^{294}$ in 1986 , this cap was shortened to thirty hours. ${ }^{205}$

It is uncertain whether the three-fifths cloture rule facilitated the passage of the 1991 Civil Rights Act. It is true that a filibuster was less of a threat in 1991 than during the passages of the 1960 and 1964 Acts, because a 1991 filibuster could have been overcome by only sixty votes. By the time cloture was finally invoked in 1991, however, extraordinary political events had created a need for compromise that allowed the motion to pass overwhelmingly. ${ }^{296}$ Furthermore, as is often the case when different parties control the White House and Congress, the possibility of a presidential veto in 1991 transformed the requirement of a simple majority to pass legislation. When a presidential veto is imminent, two-thirds of the Congress must pass a law to escape the veto threat. Given President Bush's 1990 veto and his threats of a veto throughout 1991, it seemed as though two-thirds of the Senate would be required for passage of the Civil Rights Act of 1991. In that situation, the cloture rule change from requiring two-thirds of the Senators to requiring only three-fifths would have had little visible effect. Thus, despite the important 1975 reform of Senate cloture rules, the passage of the 1991 Civil Rights Act does not readily demonstrate the impact of this reform. This circumstance serves as a reminder that congressional reforms do not operate in a vacuum: Presidential support of, or opposition to, legislation can often trump the power of congressional procedural reforms. Procedural reforms are a potent means of changing Congress, but our system of checks and balances limits their impact.

\section{CONCLUSION}

The passage of the 1991 Civil Rights Act resulted from the confluence of many factors. Significant developments in political climate and race relations undoubtedly contributed to some differences between the legislative struggles of 1960,1964 , and 1991. Similarly, specific political events in the autumn of 1991 helped to precipitate the Act's passage.

In addition, procedural changes of the 1970's played an essential role in the 1991 bill's progress. The reforms of the 1970's were enacted by liberal Democrats and moderate Republicans in an effort to wrest control of legislation away from a minority conservative coalition of Southern Democrats and conservative Republicans. That coalition exists as a visible, growing camp in many legislative battles today. The passage of the 1991 Civil Rights Act, however, demonstrates that the camp had fewer procedural weapons at its disposal in 1991 than it did in the 1960's, as a direct result of the procedural

294. TIEFER, supra note 1 , at 724 .

295. S. DoC. NO. 1, supra note 77, at 22; TIEFER, supra note 1, at 724.

296. See supra text accompanying notes 79-82. 
reforms of the 1970's. By loosening the tradition of seniority and altering the rules for committee leadership, reformers weakened a leadership system that had become a structural impediment to civil rights legislation. Furthermore, by changing the process of appointment to the House Rules Committee, House Democratic reformers turned the Rules Committee into an instrument of the leadership rather than of Democrats aligned with the minority party. These reforms aided the passage of the 1991 Civil Rights Act by empowering friendly committee leaders who were eager to move the bill to the chamber floors.

The reforms also increased the representativeness of congressional leadership. Traditions of seniority in committee chairship appointments and disproportionate power held by committee chairs had functioned as antidemocratic forces in the heart of one of our nation's most democratic institutions. The ability of committee chairs to prevent voles on picces of legislation that target issues of national concern and that are supported by the majority of members of Congress is troubling at best, and fundamentally antidemocratic at worst. The procedural reforms of the 1970's by no means eliminated the opportunities for this kind of obstruction. but they certainly diminished such opportunities. Thus, in 1991, the battles over the Civil Rights Act were waged on the chamber floors, not in debates over whether the bill would be allowed onto the floor or through invisible committee delays. This shift in the locus of political debate had a profound democratizing effect on both Congress and legislation. The weakening of the minority's chokchold on Congress was therefore the most significant contribution of the reforms of the 1970's.

With the election of the 104th Congress creating a Republican majority in both chambers for the first time in decades, congressional procedural rules have assumed renewed prominence. Indeed, House Speaker Newt Gingrich made changes in House procedure an early priority for the 104 th Congress. Gingrich seems to have learned the lessons of the 1970's reforms and is mimicking those reforms ' consolidation of the Speaker's power over committee chairs by eliminating proxy voting in committec, ${ }^{297}$ imposing term limits on committee chairships, ${ }^{298}$ and at times disregarding seniority in nominating committee chairs. ${ }^{299}$ The Senate, however, is not following the same trend; it seems to be retaining committee leadership by seniority, even in the face of recent controversy surrounding Senator Jesse Helms. ${ }^{30}$

297. Cooper \& Dewar, supra note 244. at Al

298. Adam Clymer. The 104th Congress, N Y TINES, Jan 6. 1995. al A20 (describung llouse rule changes); Cooper \& Dewar, supra note 244. at A!

299. Adam Clymer, Sirong Speaker. Sirong House" N Y Tives, Dec 4. 1(x)4. at A32 inoting Gingrich disregarded seniority in some choices of chairs)

300. Adam Clymer, Congress Returns To Select Leaders for the Nen Term, XY Y Tives. Nov 28. 1994, at Al (quoting Sen. Dole's defense of senionty system). Helen Deuar. Sasing Helms Vous To Hold His Tongue, Dole Won't Deny Him Charmanshup. WASH. POST. Nov. 24, 1994. al A25 Jesse Helms 
How these new reforms will affect legislation remains to be seen. The conservative coalition that was the target of the reforms of the 1970's now constitutes, at least for the next two years, the dominant majority in both chambers of Congress. These next two years will therefore provide an opportunity to see how factions within the Republican majority will develop as compared to those within former Democratic majorities, and how such factions will use procedural tools and reforms to enlarge their power. The politics will differ, but the importance of procedure will not. 